\title{
Bevezető: utak és úton lévők
}

\section{Introduction: ways of migration and people on the move}

\author{
VÁRADI MONIKA MÁRIA, DORIS WASTL-WALTER, FILEP BÉLA, \\ GÁBRITY MOLNÁR IRÉN
}

KULCSSZAVAK: Vajdaság, kényszermigráció, tanulmányi célú migráció, munkavállalási célú migráció, transznacionális migráció, etnikai migráció, a migránsok integrálódása, régi és új otthonok

ABSZTRAKT: A Tér és Társadalom tematikus száma egy 2010 és 2012 között, magyarországi, svájci és szerbiai kutatók közreműködésével lezajlott nemzetközi kutatás eredményeiből kínál ízelítőt. A kutatás fókuszában a Vajdaságból Magyarországra, illetve a volt jugoszláv tagköztársaságokból a Vajdaságba irányuló migráció vizsgálata és értelmezése állt. Az elmúlt bő két évtizedben a Vajdaságból való legújabb elvándorlás, a Vajdaságba irányuló migráció, közvetlenül vagy közvetve a Jugoszlávia széteséséhez és az új nemzetállamok kialakulásához vezető háborúkhoz és azok gazdasági, társadalmi, politikai következményeihez köthető. Míg a kilencvenes években a háborúk kiváltotta kényszermigráció, addig az ezredfordulót követően a tanulmányi, valamint a munkavállalási célú (gazdasági) migráció volt a meghatározó vándorlási folyamat.

A kvalitatív módszerekkel nyert kutatási eredményeink értelmezése során a transznacionális tér, a transznacionális és az etnikai migráció elméleti és szemléleti kereteit egyaránt figyelembe vettük. Az általunk vizsgált migrációs folyamatok transznacionális térben zajlanak, és a transznacionális irodalomban leírt migráns élethelyzetek, gyakorlatok - különböző nemzetállamokban elhelyezkedő lokalitásokhoz való egyidejü, bár eltérő intenzitású kötődés, kapcsolatok - több példájával is találkoztunk. Ludger Pries nyomán a transznacionális migrációt és a transznacionális migráns alakját olyan ideáltípusnak tekintettük, amelyhez az egyes migráns utak és helyzetek csupán közelítenek, és empirikus eredményeink alapján azt mondhatjuk, hogy a valóban plurilokális, vagyis a két helyhez való egyidejü, intenzív és tartós kötődés s az ehhez kapcsolódó gyakorlatok csupán a migránsok kisebbségét, illetve a migrációs életpályák egy-egy szakaszát jellemzik.

A vizsgált migrációs folyamatokban az etnicitás strukturális tényezőként és a migráns tapasztalatok értelmezési kereteként egyaránt perdöntő szerepet játszik. Az etnikai migráció szakirodalomban tárgyalt mindhárom magyarázó modellje - az anyaországba való hazatérés, a gazdasági okokból való, illetve a kisebbségi létben elszenvedett sérelmek által ösztönzött migráció - alkalmas a migrációt kiváltó és mozgató okok elemzésére, a migráns narratívák értelmezésére, azt azonban nem állíthatjuk, hogy bármelyikük kizárólagos érvényre tehet szert. Más kutatókhoz hasonlóan Rogers Brubaker meghatározását tartjuk a leginkább gyümölcsözőnek, aki az etnikai migráció tág értelmezését használva minden olyan vándorlási folyamatot etnikai migrációnak tekint, amelyben az etnicitás kulturális és szimbolikus tőkeként szabályozó szerepet játszik.

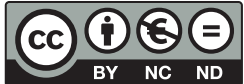


KEYWORDS: Vojvodina, forced migration, educational migration, labour migration, transnational migration, ethnic migration, integration of migrants, old and new homes

ABSTRACT: This special issue of Tér és Társadalom presents some results of an international research project carried out by researchers from Switzerland, Hungary and Serbia between 2010 and 2012. The topic of the research was "Integrating (Trans-)national Migrants in Transition States" (TRANSMIG) and was financed by the Swiss National Science Foundation (SNSF). The research aimed to explore and interpret migration flows from the Vojvodina (Serbia) to Hungary and from ex-Yugoslav republics to the Vojvodina. In the first period of the last twenty years, wars which contributed to the disintegration of Yugoslavia and the formation of new national states have caused migration flows. After the change of the millennium, educational migration of Vojvodina Hungarian youth can be considered the most important migratory movement from the Vojvodina to Hungary. Labour (economic) migration also occurs, but this cannot be understood as a one-way movement, since in the Hungarian-Serbian border zone migrants from the Vojvodina who already resettled to Hungary commute to the Vojvodina.

While interpreting the qualitative research data the theoretical frameworks and approaches of transnational space, transnationalism and ethnic migration were taken into consideration. The migration movement in question occurs in a transnational social space where migrants are in constant motion. By their movements and actions that space is continually recreated. With Ludger Pries we see a transnational migrant as an ideal type to whom individual migratory movements and positions only approximate. Based on our empirical results we can conclude that real pluri-local, intensive and long-lasting bonding to two places at the same time and the relating practices only characterise a minority of migrants and certain sections of migratory careers.

In the migration processes studied, ethnicity as a term is needed as a "structural factor" and frame of interpretation to approach migrant experiences. All three explanatory models for ethnic migration - return migration, economic migration, migration motivated by grievances suffered in a minority situation - are suitable to analyse the reasons that initiated migration and kept it in motion. They are helpful in interpreting migrant narratives. However, none of the reasons can claim exclusive validity. Agreeing with other researchers, we find Roger Brubaker's definition the most useful: Ethnic migration should be comprehended in a broad sense. In addition, every migration can be considered as "ethnically" motivated where ethnicity plays a dominant role as a cultural and symbolic capital.

\section{A tematikus szám apropója: egy nemzetközi migrációs kutatás}

A Tér és Társadalom olvasói egy tematikus számot tarthatnak a kezükben, amely eltérve a folyóirat megszokott szerkezetétől kizárólag tanulmányokat, kutatási eredményeket bemutató írásokat tartalmaz. A szóban forgó, 2010 és 2012 között lezajlott nemzetközi kutatás az „Integrating (Trans)national Migrants in Transition States" (TRANSMIG) címet viselte, támogatója a Swiss National Science Foundation (Svájci Nemzeti Tudományos Alap) volt. ${ }^{1}$ A kutatási projekt vezetésével, koordinálásával összefüggő feladatokat a Berni Egyetem Földrajz Tanszéke (Geographisches Institut der Universität Bern) látta el, szakmai vezetője Prof. Dr. Doris Wastl-Walter volt, megvalósításában szerbiai és magyarországi intézmények kutatói vettek részt. A projektben Szerbiából a szabadkai székhelyü Magyarságkutató Tudományos Társaság és az Újvidéki Egyetem Földrajz, Turizmus és Hotelmenedzsment 
Tanszéke (Departman za Geografiju Turizam i Hotelijerstvo), míg Magyarországról az MTA Földrajztudományi Kutatóintézete (2012. január 1. óta MTA Csillagászati és Földrajztudományi Kutatóközpont Földrajztudományi Intézet), valamint az MTA Regionális Kutatások Központja (2012. január 1. óta MTA Közgazdaság- és Regionális Tudományi Kutatóközpont Regionális Kutatások Intézete) munkatársai működtek közre. A projekt megvalósítóinak körét elsősorban a támogató alap kiírása alakította. A pályázaton egy svájci vezető partner és egy EU-n kívüli tagállam kutatóinak konzorciuma indulhatott, de lehetőség volt egy uniós tagország kutatóinak csatlakozására is. A kutatócsoport korábbi együttmüködések mentén alakult, s a téma a résztvevők érdeklődésének megfelelően, illetve előzetes kutatási tapasztalataira támaszkodva formálódott kutatási programmá.

A kutatás középpontjában a Vajdaságból Magyarországra, illetve a volt jugoszláv tagköztársaságokból a Vajdaságba irányuló migráció vizsgálata és értelmezése állt. Nagyon egyszerüen fogalmazva, arra kerestük a választ, hogy az 1990-es évek eleje óta kik, miért indultak útnak, hagyták maguk mögött időlegesen vagy végleg a szülőföldjüket; milyen nehézségekkel kellett szembenézniük új lakóhelyükön, sikerült-e „integrálódniuk” a befogadó ország viszonyaiba, az új otthonaikat jelentő lokális közösségekbe, milyen kapcsolatokat tartanak fenn régi lakóhelyükkel, szülőföldjükkel.

Mivel a Vajdaságot akár kibocsátó, akár befogadó tartományként érintő és jelentős mértékben átalakító migrációs hullámok a Jugoszlávia széteséséhez és új nemzetállamok kialakulásához vezető polgárháborúhoz köthetők, kutatásunk is erre az időszakra fókuszált. Noha a migráció adatokból, korábbi elemzésekből feltárható történelmi dinamikája is érdekelt bennünket - erről e számban olvashatnak is az érdeklődők Tátrai, Kocsis, Gábrity, Takács (2013) tollából -, a közelmúltra koncentráltunk, és arra törekedtünk, hogy magukat az érintett szereplőket szólaltassuk meg, hogy elmesélhessék megélt történetüket.

\section{A módszerről}

Kvalitatív módszert választottunk tehát, félig strukturált interjúkat készítettünk különböző migránsokkal: Magyarországon élő vajdaságiakkal, ${ }^{2}$ Vajdaságban élő szerb menekültekkel, a szerb-magyar határon ingázó vajdaságiakkal, Magyarországon felsőfokú tanulmányokat folytató vajdasági diákokkal. A kérdések a migráció körülményei, a migrációt megelőző életviszonyok, a migrációt követő események, a beilleszkedés, az egyéni és családi perspektívák körül forogtak. Alapvetően mind a magyarországi, mind a vajdasági kutatócsoportok a saját országukban készítettek interjúkat, kivételt azok az interjúk jelentettek, amelyeket az MTA kutatói készítettek temerini magyar lakosokkal.

Mivel nem léteznek olyan adatbázisok, nyilvántartások - mi legalábbis nem fértünk hozzá ilyenekhez -, amelyek segítségével egy statisztikai szem- 
pontból releváns minta alapján választhattuk volna ki interjúalanyainkat, a hólabdamódszer alkalmazásával tudtuk elérni őket. Arra kértük a beszélgetőpartnereinket, hogy ismerőseik, barátaik köréből ajánljanak olyan embereket, akik szívesen vállalkoznának egy beszélgetésre; a legelső interjúalanyok jellemzően a kutatók ismerősei közül kerültek ki. A Magyarságkutató Tudományos Társaság munkatársai Szabadkán, Zentán, Magyarkanizsán készítették interjúik többségét, az újvidéki egyetemi kollégák Temerint választották kutatási terepül, míg a magyarországi kutatók a vajdasági migránsok területi koncentráltságának megfelelően a legtöbb interjút Budapesten és Szegeden élőkkel készítették. Utóbbi kutatócsoportnak rendkívül értékes támogatást nyújtott a Vajdasági Magyarok Demokratikus Közössége (VMDK) Szegedi Tagozatának elnöke, Nagy Abonyi Attila, aki a szervezet tagsága és támogatói körében segített megtalálni az interjúra vállalkozó áttelepült vajdaságiakat.

Természetesen tisztában vagyunk azzal, hogy eredményeink nem tekinthetők reprezentatívnak abban az értelemben, hogy a kutatásba bevont, illetve abban megjelenő migránsok társadalmi státus, iskolai végzettség stb. tekintetében megjelenítenék a teljes vajdasági migráns népességet. A Magyarországon élő interjúpartnereink többsége diplomás, értelmiségi foglalkozású vagy müvész, ami torzít, hisz nyilvánvaló, hogy nem csupán magasan kvalifikált emberek hagyták el a Vajdaságot. Ugyanakkor korábbi kutatási tapasztalatok (Gábrity Molnár, Mirnics 2001; Tóth 1997) arról tudósítanak, hogy a vajdasági magyar értelmiségi, művész- és médiaelit jelentős számban emigrált a polgárháború idején, Magyarországra vagy tovább.

A választott módszer korlátainak tudatában is úgy gondoljuk, hogy az elkészült nagyszámú interjúból ${ }^{3}$ az élettörténetek egyedisége mellett is kibontakoznak azok a tipikusnak mondható pályák, amelyeket a vajdasági migránsok bejártak, bejárnak.

E tematikus számban különböző megközelítésű, szemléletű és fókuszú tanulmányok mutatják be kutatási eredményeinket. Az interjúk feldolgozásának és elemzésének más útjai is lehetségesek, a gazdag anyag pedig lehetőséget kínál további tematikus feldolgozásra. Bevezetőnkben azonban csak arra vállalkozhatunk, hogy röviden tárgyaljunk néhány olyan mozzanatot, amelyek nem jelennek meg részletesen, hangsúlyosan a tanulmányokban, illetve felvázoljuk azokat az elméleti, szemléleti kereteket, amelyek lehetőséget nyújtanak az eredmények - nem kizárólagos - értelmezésére.

\section{Felvezetés: migránsok, kényszerü és önkéntes döntések, eltérő migrációs folyamatok és tapasztalatok}

Kevés olyan beszélgetőpartnerünk volt, akinek családjában vagy saját életében jellemző lett volna a külföldi, elsősorban németországi vendégmunka, ez a tö- 
meges jugoszláv megélhetési és életstratégia. ${ }^{4} \mathrm{Az}$ is csak néhány esetben fordult elő, hogy vajdasági magyar fiatalok a szocializmus éveiben, államközi egyezmény alapján, Magyarországon végezték felsőfokú tanulmányait, ők haza is tértek, otthon akartak boldogulni. Mindössze két olyan asszonnyal beszélgettünk, akik még a nyolcvanas években jöttek Magyarországra. Egyikük egyetemi oktatóként nem tudta elviselni az őt körülvevő, magyarokkal szemben ellenséges szerb környezetet, áttelepült Magyarországra, ami az otthont, a biztos menedéket jelentette számára. ${ }^{5}$ Másikuk a nyolcvanas évek elején, az emblematikus újvidéki magyar folyóirat, az Új Symposion ${ }^{6}$ elleni politikai támadás után „sétált át” a határon.

A megkérdezettek túlnyomó többsége a Jugoszlávia széteséséhez vezető háborúk miatt kényszerült elhagyni otthonát. A vajdasági Temerinbe nagy számban érkeztek horvátországi és boszniai szerb családok, akik mindent hátrahagyva menekültek el korábbi otthonaikból. Vajdasági magyar férfiak tömegei szöktek át a behívók elől Magyarországra. A beszélgetésekben rendre hallottunk történeteket arról, miként bujkáltak a férfiak, hogy ne találják őket otthon, amikor hozzák a behívót; heteken, hónapokon át „egymás feleségeinél” aludtak; ha éppen akkor kopogtak, csengettek az ajtón, amikor otthon voltak, az asszony nyitott ajtót $\mathrm{s}$ tagadta le a férjét. Kevés olyan emberrel beszélgettünk, aki meg tudta tervezni áttelepedését Magyarországra, ők jellemzően otthon is gazdasági vezetőként, majd Magyarországon vállalkozóként dolgozó férfiak, akik a nyolcvanas évek végén már látták a mélyülő gazdasági krízist és sejtették, hogy az háborúhoz vezet. Másoknak valamilyen - jellemzően egészségügyi - okból nem kellett tartaniuk a behívástól, így otthon maradva tervezték és szervezték meg áttelepedésüket Magyarországra, a hivatalos utat bejárva szerezték be a szükséges dokumentumokat. A többség nem tervezett, gyakran egyik napról a másikra kellett dönteniük és felkerekedniük, néha igen „kalandos” körülmények között sikerült csak átkelniük a határon. ${ }^{7}$

A kilencvenes évek tömeges migrációját a délszláv háborúk sora és az ezeket kísérő gazdasági válság kényszerítette ki, senkivel nem találkoztunk, aki önként elhagyta volna a szülőföldjét, beszélgetőtársaink zöme megállapodott egzisztenciával rendelkezett akkor, amikor 1991-ben elkezdődött a háború. Többen húsz év távlatából visszatekintve is újraélték azt a döbbenetet, értetlenséget, amellyel az akkori változásokat szemlélték; a mindennapokat és a korábban magától értetődő multietnikus, jószomszédi kapcsolatokat mérgező nacionalizmus térhódítását, a háborús erőszakot, amelyben nem akartak részt venni. ${ }^{8}$

A legtöbben ideiglenesnek gondolták a távollétet, azt remélték, hamarosan elülnek a konfliktusok, konszolidálódik a helyzet és hazatérhetnek. ${ }^{9} \mathrm{Az}$ ideiglenesség reménye vezetett sokakat a közeli Szegedre a kilencvenes években; akkoriban - idézik fel a visszaemlékezők - a sétálóutcán lépten-nyomon vajdasági honfitársakba ütközött az ember, akik aggodalmasan tárgyalták az otthoni híreket, s azt latolgatták, vajon mikor térhetnek végre haza. Ezért vállalta több család is hosszú hónapokon át a kétlakiságot; a feleség a gyerekekkel otthon maradt, s 
látogatta Szegeden vagy másutt lakó férjét. Azután ők is áttelepedtek. A hazatérés ideje egyre távolabbra tolódott, be kellett rendezkedni Magyarországon is, élni, dolgozni kellett, az ideiglenesnek szánt tartózkodás véglegessé vált.

A kilencvenes évek eleje óta folyamatosan jelen van és napjainkra meghatározó migrációs folyamattá vált a vajdasági magyar fiatalok tanulmányi célú migrációja is, amelyben eleinte tetten érhető volt a háború és következményeinek: az embargó, infláció, NATO-bombázások, az elhúzódó bizonytalanság kényszerítő hatása (Erőss, Filep, Rácz, Tátrai, Váradi, Wastl-Walter 2011a, 2011b). Kétségtelen ugyanakkor, hogy az ezredfordulót követően, még ha a magyarországi továbbtanulásról szóló döntésekben meg is jelennek a mobilitási és boldogulási lehetőségek szűkösségéből fakadó kényszerítő elemek, e migráció önkéntes egyéni és családi döntéseken alapul.

A kényszerítő körülmények, azaz a megfelelő munka- és kereseti lehetőségek hiánya tetten érhető a munkavállalási célú migrációban is, amely napjainkban kétirányú mozgást jelent; nemcsak olyan vajdaságiakról tudunk, akik magyarországi munkahelyre ingáznak, hanem olyanokról is, akik már Magyarországon élnek és onnan ingáznak a Vajdaságba, mert ott találtak a maguk számára elfogadható munkát vagy egyszerủen csak vágyódtak vissza. Arra is akad nem egy példa, hogy valaki itt is, ott is dolgozik, napi, heti, havi rendszerességgel ingázik a határon át. A munkavállalás lehet a végleges magyarországi letelepedéshez vezető első lépés is, a földrajzi és társadalmi értelemben egyaránt tudatosan épített mobilitási pálya eleme. ${ }^{10}$

A migránsok történeteiben a migrációt kiváltó okokban és motivációkban, a menekülés vagy áttelepedés körülményeiben és a megélt tapasztalatokban természetesen generációs különbségek is megragadhatók. A kilencvenes években a háború miatt Magyarországra áttelepedettek egy része még ma is beszél a migrációt kiváltó kényszerről és az azt kísérő veszteségekről, amely akkor is maradandó tapasztalat és élmény, ha az érintettek teljes mértékben beilleszkedtek a magyarországi világba, s otthon érzik itt magukat. ${ }^{11}$ Egy, a Magyarországon élő vajdaságiak migrációját, magyarországi meggyökeresedését vizsgáló szakdolgozat szerzője - maga is vajdasági migráns - a fájdalmat, gyászt, az új környezetbe való megérkezést követő elhúzódó bizonytalanságot, az otthontalanság érzését a kényszerű vándorlással, az anyagi, érzelmi és szimbolikus értékek elveszítésével járó lelkiállapotnak tekinti (Szabó 2011). ${ }^{12}$ A veszteség érzését erősítheti, hogy családok, baráti társaságok szóródtak szét, élnek szerte a világban, távol egymástól, a korábbi szoros kapcsolatok elhalványulnak, átalakulnak, újakat kell találni és kiépíteni.

Szemben azokkal, akik a kilencvenes években, fiatalabb vagy idősebb korban, kényszerüségből hagyták el a volt Jugoszláviát, azok a fiatalok, akik ebben az időszakban még gyerekek, kiskamaszok voltak, és Magyarországra az ezredforduló után tanulási céllal érkeztek, más élményekkel rendelkeznek a háborúról, másként élik meg és értelmezik a maguk vándorlásait. A kilencvenes évekből az embargó és az infláció következményeként fellépő hiányra, szűkös- 
ségre emlékeznek, hangsúlyozva, hogy szüleik mindent megtettek azért, hogy ők a nehézségekből semmit se érezzenek. A NATO-bombázásokra visszatekintve pedig néha a kellemes élményeket idézik fel: mennyire örültek, hogy a megszakított oktatás miatt nem kellett iskolába járniuk, ez volt életük leghosszabb vakációja; hogy az elsötétített fötéren, ahol a falu fiatalsága összegyűlt beszélgetni, el lehetett szívni az első cigit, meginni az első sört, „az első csók, ilyesmik”. A tanulmányi célú migráció e generáció esetében az életút tervezett része (a döntést a család hozza meg, amelyet a fiatalok kényszerként is megélhetnek), s az új környezethez való alkalmazkodás is könnyebb.

Az elbeszélésekből az is kitűnik, hogy a család szerepe megkerülhetetlen és perdöntő a migrációs folyamatokban, a migrációs döntések a legritkább esetben egyéni döntések. Jellemző, hogy családok - férj, feleség, gyermekek - együtt kerekednek fel, a temerini szerb menekültek történetei erről tanúskodnak, s így volt ez a családos vajdasági magyar migránsok körében is, ha a teljes család nem is indult rögtön útnak. A behívó elől a határon átszökő férfiak is tudták és érezték a szülők, testvérek, házastársak egyetértését és támogatását. ${ }^{13} \mathrm{~A}$ hosszabb-rövidebb ideig különélő családok élete sok áldozattal járt, amit azonban segített elviselni a megpróbáltatásokkal csak erősödő érzelmi kötelék; azokat pedig, akik féltek a hazatéréstől, az őket látogató szülők, testvérek kapcsoltak a szülőföldhöz. Nem egy esetben a család maga volt a migráció egyik oka. Példaként említhetjük azt a férfit, aki maga nem tervezte az áttelepedést, de Magyarországon diplomázott párját követve költözött ide. Ha csak egy-két esetben is, az érintettek azért jöttek el Vajdaságból, mert magyarországi házastársat találtak maguknak. ${ }^{14} \mathrm{~A}$ vajdasági magyar migránsok között is találkoztunk a másodlagos migráció (Gödri 2004) jelenségével. Így például egy olyan asszonnyal, aki közel ötvenéves volt, amikor Szegedre költözött, hogy fiaihoz közelebb lehessen. A kisebbik a katonai behívó elől Angliába menekült, ott alapított családot, a nagyobbik először Szegedre telepedett, ám mire édesanyja átjött, már továbbköltözött Budapestre. Egy mérnökembert is említhetünk, aki 1992-ben jött Szegedre, három albérletben töltött év után tudott egy kis lakást vásárolni, s ekkor hozta át magához az általános iskolát éppen befejezett leányát.

A szűkebb vagy tágabb család tekinthető a migrációs hálózatok egy láncszemének is, erről a tanulmányi célú migrációt tárgyaló korábbi írásainkban (Erőss, Filep, Rácz, Tátrai, Váradi, Wastl-Walter 2011a és 2011b) és e tematikus szám néhány tanulmányában is szó esik. A vajdasági Temerin azért is válhatott olyan sok menekült új lakóhelyévé, mert a korábbi migrációs hullámokkal idekerült és letelepedett rokonság információkat, hathatós segítséget és érzelmi biztonságot nyújtott az otthonukat elhagyni kényszerülő családoknak. Vajdasági magyar beszélgetőpartnereink is gyakran említették a már Magyarországon élő rokonaik, barátaik, ismerőseik vagy „egy ismerős ismerősének” segítségét az áttelepedést követően; volt hol meghúzni magukat, információkat kaptak, amelyek segítettek eligazodni a hivatalos útvesztőkben, helyzetük legalizálásában. Sajátos érdekvédelmi szervezetként jött létre a VMDK Szegedi Tagozata is. Miu- 
tán nyilvánvalóvá vált, hogy a jugoszláviai helyzet nem normalizálódik s egyre többen érkeztek Szegedre, a migránsok szükségesnek látták, hogy megszervezzék magukat, ${ }^{15}$ és így minden lehető módon segítsék áttelepülő, menekült honfitársaikat, egy olyan helyet biztosítsanak számukra, ahol „az otthon ízeit megtalálják" (Szabó 2011). ${ }^{16}$ Hatékony migrációs hálózatként működött az a fövárosi nyomda, amelynek nemcsak tulajdonosai vajdasági magyarok, hanem majd' összes dolgozója is; e vállalkozás a vajdaságiak széles körében ismert arról, hogy munkahelyet kínál, és így segít a letelepedéshez szükséges papírok beszerzésében, a migránsok helyzetének rendezésében.

Az általunk vizsgált migrációs folyamatok néhány általános jellemzőjének felvázolása után a következőkben azokról az elméleti megközelítésekről lesz szó, amelyek kutatási eredményeink értelmezését segítik és a szakmai diskurzusokhoz kapcsolják.

\section{Értelmezési keretek}

\section{A transznacionalizmus kihívásai}

Már kutatásunk címe tartalmazta a „(transz)nacionális migráns” fogalmát, a közös munka során pedig mindvégig törekedtünk arra, hogy tisztázzuk, a transznacionális migráció, a transznacionális tér, a transznacionalizmus diskurzusa és kutatási eredményei mennyiben relevánsak az általunk vizsgált, alapvetően etnikai migrációs folyamatok megértésében és értelmezésében. $\mathrm{E}$ bevezető tanulmányban nem vállalkozhatunk a transznacionális migráció témakörében született gazdag, szerteágazó irodalom beható elemzésére, csupán néhány, számunkra fontos összefüggésre hívnánk fel a figyelmet; e tematikus szám néhány tanulmánya (Takács, Tátrai, Erőss 2013; Tátrai, Kocsis, Gábrity Molnár, Takács 2013, Váradi 2013) is reflektál a transznacionalizmushoz kötődő fogalmak és szemléletmód alkalmazhatóságának kérdésére.

Klasszikus munkájukban Basch és szerzőtársai a transznacionalitás fogalmával azt a jelenséget írják le, hogy a migránsok egy másik országban letelepedve, élve sem szakadnak el származási országuktól, sokféle - családi, gazdasági, szociális, vallási, kulturális, politikai - kapcsolatot tartanak fenn a kibocsátó országgal, viszonyaik, aktivitásaik egyszerre két vagy akár több nemzetállamhoz kötik őket (Basch, Glick Schiller, Szanton Blanc 1994, 7.). A migránsok kötődése hajdani hazájukhoz, az otthoniakkal való kapcsolattartás kétségkívül élő gyakorlat a vajdasági migránsok többségénél, az is nyilvánvaló azonban, hogy a jelenség nem tekinthető újdonságnak, vagyis a transznacionalitás, a transznacionális migráció fogalmának és kutatási programjának megjelenése előtt is létezett. E tekintetben a különbség a 19. századi amerikai 
bevándorlók és korunk migránsai között az, hogy a 20. század új közlekedési és telekommunikációs technológiái tömegessé és mindennapivá tették a nemzeti határokon és akár földrésznyi távolságokon átívelő kapcsolattartást (lásd például Portes 2003). S ugyan élhetünk olyan értelmezéssel is, amely szerint a politikai és nemzeti határokon átívelő migrációt a legáltalánosabb és legtágabb értelemben transznacionális migrációnak nevezhetjük (Jordan, Düvell 2003), inkább azokkal értünk egyet, akik szerint a nemzeti határokon átívelő migráció önmagában nem azonos a transznacionális migrációval, s hogy a transznacionális gyakorlatok csupán a migránsok kisebbségét jellemzik (lásd Dahinden 2005; Portes 2003). ${ }^{17}$

A transznacionális migráció, a transznacionális társadalmi tér elméleti koncepciójának, kutatási programjának egyik újdonsága abban rejlik, hogy szakítva a „módszertani nacionalizmussal” (lásd például Wimmer, Glick Schiller 2002a, 2002b), feloldotta a zárt nemzetállamokról alkotott elképzeléseket. „A transznacionális társadalmak (...) földrajzi értelemben nem kötött társadalmat, illetve társadalmi működéseket feltételeznek. Az elmozdulás a lokalitások között nem egyszeri, hanem többszöri oda-vissza mozgás is lehet, a jövőre vonatkozó perspektívákat is a nyitva hagyott lehetőségek jellemzik, így jön létre (...) a lebegésnek az állapota (...). Ez a »lebegés« akár állandósulhat is, más esetekben viszont a migráns kilép ebből az állapotból (...), és személyes kapcsolatait, jövőre vonatkozó elképzeléseit, tartózkodását tekintve az egyik lokalitás fontossága megnő." (Feischmidt, Zakariás 2010, 159.).

Más szerzők azt hangsúlyozzák, hogy a migráció transznacionális kutatása „nem annyira a (többé-kevésbé) empirikus jelenségek sorát jelenti, mint inkább egy (többé-kevésbé) teoretikus perspektívát, a migráció sajátos felfogását. (...) Ebben az esetben nem az a kérdés, hogy egy migrációs folyamat milyen mértékig transznacionális, hanem az, hogy a transznacionális perspektíva segítségével hogyan tudjuk megérteni általában és egy-egy specifikus formájában a migrációs folyamatokat" (Gustafson 2004, 68-69.).

A kérdésünk tehát az, hogy az általunk vizsgált, megismert migrációs folyamatok között vannak-e olyanok, amelyek megértésében, értelmezésében a transznacionális perspektíva és szemlélet gyümölcsöző lehet.

Ludger Pries értelmezésében „a transznacionális és transznacionalizálódás fogalma olyan, határokon átívelő jelenségeket fog át, amelyek - különböző nemzeti társadalmakban lévő lokalitásokhoz kötötten - viszonylag tartós és sürü társadalmi kapcsolatokat, hálózatokat vagy társadalmi tereket hoznak létre" (Pries 2010,13.). ${ }^{18} \mathrm{~A}$ transznacionális kapcsolatok, hálózatok és terek tartósságuk, intenzitásuk, gyakoriságuk, az egyes emberek életében betöltött jelentőségük mentén különböznek egymástól és egyfajta sorba rendeződnek. Saját kutatási tapasztalatunkból említve példát, az otthon maradt vagy a világban szétszóródott hajdani osztálytársakkal fenntartott internetes kapcsolatok, a többé-kevésbé rendszeres hazalátogatások a migránsok többségének életében fontos szerepet játszanak; a budapesti jugóbulik főszervezője által létrehozott, országokat átívelő, különböző nemzetiségű embe- 
reket összekötő facebookos közösség viszont mozgósítható transznacionális hálózatként működik. Pries a transznacionalizálódást, a nemzetállami határokon átívelő geográfiai és társadalmi terek egyik ideáltípusaként, „társadalmi gyakorlatok, termékek, szimbolikus rendszerek alakzataiként" ${ }^{19}$ definiálja, amelyek „legalább két nemzetállamban található, különböző földrajzi helyeket kötnek össze" (Pries 2001, 18., e definíciót idézi Váradi 2013 tanulmánya is e számban). ${ }^{20}$

A kutatásunk által érintett, a magyar-szerb államhatár által elválasztott teret - amely Magyarországot és Vajdaságot fogja át, ugyanakkor egy tágabb európai és globális tér részét képezi - abban az értelemben tekinthetjük transznacionális térnek, hogy az itt élők, illetve az innen elszármazottak egy részének élete nemcsak a határ egyik vagy másik oldalán található lakóhelyéhez kötődik, hanem eltérő módon és intenzitással a másik országban elhelyezkedő településekhez (lokalitásokhoz) is füzik különböző kapcsolatok, gyakorlatok.

A két nemzetállam közötti határon különböző gyakorisággal emberek járnak ide-oda. Vannak köztük napi vagy távolsági ingázók, hétvégenként hazajáró középiskolások, egyetemisták, valamelyik magyarországi doktori iskola hallgatói, magyarországi továbbképzésekre, táborokba járó vajdasági magyar pedagógusok, iskolások, bevásárló vagy pihenő turisták, szüleiket, rokonaikat látogató migránsok, valamely multinacionális cég telephelyi képviselői, a határ mindkét oldalán üzleti kapcsolatokat ápoló vállalkozók - s a lista valószínűleg tovább bővíthető. $\mathrm{E}$ térben források, javak, tárgyak, szimbólumok mozognak, cserélődnek. Ingázó munkások hozzák, küldik haza a fizetésüket, mások az otthoni szülöi ház karbantartására, felújítására fordítják magyarországi megtakarításaikat; a hazalátogatók kocsija tele van pakolva odafelé rokonoknak, ismerősöknek szánt ajándékokkal vagy éppen gyógyszerrel, visszafelé a hazai finomságokkal és cigarettával. Az emberekkel együtt kulturális javak is áramlanak oda-vissza e térben. Csupán néhány példát említünk. Vajdaságból Magyarországra áttelepedett egyetemi emberek rendszeresen részt vesznek a vajdasági tudományos és felsőoktatási életben, konferenciák állandó meghívottjaként, tudományos diákköri konferenciák zsüritagjaként. Ahogy a szegedi vajdasági bálba vajdasági zenészeket hívnak, úgy az is előfordul, hogy Magyarországon élő vajdasági zenészeket hívnak haza lakodalomba zenélni. Egy Budapesten élő előadóművész rendszeresen jár haza szavalóversenyek zsürijébe, s lép fel szülővárosában. A kishegyesi Dombosfeszt egyik szervezője a Budapesten élő, de szülőfalujában, Kishegyesen is házat építő művészeti menedzser. ${ }^{21} \mathrm{E}$ teret egyúttal sürü és intenzív határon átívelő kommunikáció hálózza be, a kapcsolattartást a személyes látogatásokon túl a mindennapokban a mobiltelefon, az internet, a Skype, a különböző közösségi portálok segítik és könnyítik. Az általunk vizsgált migrációs folyamat a priesi értelemben felfogott transznacionális társadalmi térben zajlik, a migráció résztvevői e térben mozognak s egyúttal újra is teremtik e teret. Ugyanakkor le kell szögeznünk, hogy a valóban plurilokális, vagyis a két helyhez való egyidejü, intenzív és tartós kötődés s az ehhez kapcsolódó gyakorlatok csupán a migránsok kisebbségét jellemzik. 


\section{Migráns ideáltípusok és élethelyzetek}

Pries a kibocsátó és befogadó országhoz füződő kapcsolat jellege, a migráció tipikus (gazdasági, társadalmi, kulturális, vallási, politikai) kontextusa, valamint a migráció időtávlata mint dimenziók mentén a nemzethatárokon átívelő migráció, illetve a migráns alakjának négy ideáltípusát rajzolja fel (Pries 2010, 59-62.). Hangsúlyoznunk kell, hogy ideáltípusokról van szó, az egyes élethelyzetek csupán közelíthetnek valamely típushoz, és nem is kőbe vésettek, hanem nyitottak, egyikből a másikba fordulhatnak akár egy generáción belül, akár generációk között.

1. Az elvándorlás és bevándorlás klasszikus modelljében a migráns/immigráns gazdasági, politikai okból, önként vagy kényszerből felkerekedik, s noha kapcsolatot tart az otthoniakkal, fokozatosan integrálódik a befogadó országba, amely - ha csak a következő generációk számára is - új hazává válik. A nagy bevándorló országok, így Németország népességének jelentős részét ilyen bevándorlók, illetve leszármazottaik alkotják. A Horvátországból és Boszniából Temerinbe érkező menekültek, valamint a Vajdaságból a háborúk elől Magyarországra költöző családok élete vélhetően az el- és bevándorlás e klasszikus modellje szerint alakul. Az otthonnal ápolt gyakran rendkívül intenzív kapcsolatok, az erős érzelmi kötődés az első generációt jellemzi, s csak szabályt erősítő kivételként hallottunk olyan részben vagy teljesen Magyarországon felnőtt gyerekekről, akik nemcsak vajdasági magyarnak tartják magukat, s hazajárnak nagyszüleikhez, rokonaikhoz, hanem tudatosan ápolják vajdasági kapcsolataikat és identitásukat. A második generáció teljesen beilleszkedett Magyarországon, amelyet az otthonuknak, hazájuknak tekintenek, iskoláik, barátaik, párjaik idekötik őket. Ha egyszer innen elmennek, már Magyarország lesz a kibocsátó ország.

2. A visszatérő migráció azokat a migránsokat jellemzi, akik időszakosan mozognak országok között, rendszerint azért, hogy munkát vállalva pénzt keressenek, s addig tartózkodnak más országban, ameddig a szükségesnek tartott pénzt elő nem teremtik. A Németországban vagy más európai országban dolgozó jugoszláviai vendégmunkások mellett a Magyarországon munkát vállaló székelyföldi (lásd például Bodó 2008; Pulay 2005) és vajdasági vendégmunkásokat (Szabó 2003) is említhetjük. ${ }^{22}$ A visszatérő migráns nem tervezi a letelepedést a befogadó országban. A válságos kilencvenes években Magyarországon vendégmunkát vállaló feketicsi és kishegyesi vendégmunkásokkal készített interjúkból kiderült, hogy hosszabb-rövidebb idő után mindannyian döntöttek a véglegesnek szánt hazatérésről. „A vendégmunka vállalását kivételes alkalomnak tartják, ami nem szerves része az életpályának" (Szabó 2003, 248.). Mi is találkoztunk olyan, ötvenes éveiben járó vajdasági asszonnyal, aki 2007 óta egy Budapest környéki multinacionális cégnél dolgozik, munkásszállón lakik nem egy vajdasági, felvidéki és erdélyi magyar kollégájával. Havonta jár 
haza, fizetésosztás után, „hogy a gyerekeimnek legyen miból megélnie”. Noha elégedetlen a fizetésével és munkahelyén előmeneteli lehetősége sincs, nem tud hazatérni, mert otthon nem talál munkahelyet. Nem lehet tudni, hogy mikor térhet vissza s adja fel végleg a vendégmunkás létet. A visszatérő migráció más eseteivel is találkoztunk: vannak, akik nem akartak/tudtak Magyarországon megtelepedni, ezért visszamentek a Vajdaságba; s vannak, akik még csak tervezik, hogy nyugdíjas éveiket szülőföldjükön töltik.

3. A nemzetközi migráció harmadik ideáltípusa a diaszpóramigráció, amelynek hátterében Pries elsősorban politikai, vallási, erős lojalitási és szervezeti függőségi viszonyokat azonosít (utóbbiakra példaként egyházak, diplomáciai testületek, transznacionális vállalatok, nemzetközi alapítványok stb. munkatársait említi). A diaszpóramigráns ugyan fizikai, térbeli, gazdasági és talán politikai értelemben is beilleszkedik valamilyen mértékben a befogadó országba, de ottlétét ideiglenesnek, rövid, legfeljebb középtávúnak tekinti. A diaszpóramigránsokat nagyon erős érzelmek, kötelékek füzik az „ígéret földjéhez”, ahonnan gyakran elűzték, elüldözték őket, ahová vissza kívánnak térni (például zsidó, örmény diaszpóra) vagy az „anyaszervezetükhöz". A migráció ezen priesi ideáltípusához akárcsak közelítő élethelyzetet nem tudtunk azonosítani kutatásunk során. ${ }^{23}$

4. A transznacionális migrációban résztvevő, az azt megjelenítő migránsok, „transzmigránsok” esetében a különböző országok, helyek közötti mozgás nem egyszeri vagy periodikus, a plurilokalitás szélsőséges esetben az élet normális állapotává válik, a migráció kimenetele, az esetleges letelepedés időben elhúzódó, fokozatosan végbemenő folyamat. A transzmigráns tulajdonképpeni alakját a karib-tengeri országokból az USA-ba vándorló s az otthoni nagycsaláddal és az országgal intenzív kapcsolatot ápoló migránsokról szóló kutatások írták le és teremtették meg (lásd például Basch, Glick Schiller, Szanton Blanc 1994). Ehhez az ideáltípushoz - életüknek legalábbis egy szakaszában - a Magyarországon közép- és felsőfokú tanulmányokat folytató diákok állnak legközelebb (lásd ehhez Erőss, Filep, Rácz, Tátrai, Váradi, Wastl-Walter 2011a, 2011b; Takács, Tátrai, Erőss 2013, Váradi 2013 e számban), hogy azután a klasszikus modellnek megfelelően letelepedjenek Magyarországon, esetleg másutt, vagy visszatérő migránsként hazatérjenek szülőföldjükre. Bizonyos mértékig azok a migránsok is e típushoz közelítenek, akik munkavállalási céllal lépik át a nemzetállamokat elválasztó határokat. Vannak közöttük visszatérő migránsok, akik tanulmányaik végeztével hazatelepedtek, s noha lakóhelyük Vajdaságban van, két munkahelyen dolgoznak (lásd ehhez Karolina történetét Váradi 2013 tanulmányában). Mások ugyan családjukkal együtt Szegeden élnek, de vajdasági munkahelyre ingáznak. Mint egy ötvenes éveinek végén járó férfi, aki 1991-ben jött Magyarországra. Mindenféle munkával próbálkozott, végül megelégelte, hogy nem talál pedagógus végzettségének megfelelő állást, ezért 2003-ban elkezdett in- 
gázni vajdasági munkahelyére. Mindkét településen rendelkezik ingatlannal, azt tervezi, hogy nyugdíjas korában végleg visszatér vajdasági szülőfalujába. ${ }^{24} \mathrm{~S}$ van olyan, ötvenes értelmiségi, aki ugyan a háborúk idején sem hagyta el Vajdaságot, de már a nyolcvanas években is szoros kapcsolatokat épített ki magyarországi (akkor ellenzéki) értelmiségi körökkel, ugyanakkor a vajdasági irodalmi életbe is intenzíven bekapcsolódott. Munkája, szakmai, baráti kapcsolatai azóta is Vajdasághoz és Magyarországhoz, szorosabban Újvidékhez - ahol szerb nyelven oktat az egyetemen - és Szegedhez - ahol doktori címét is szerezte, s ahol hosszú évek óta tanít - kötik, mindkét világban otthonosan érzi magát és otthonosan mozog. „Nekem nagyon fontos, hogy menjek Magyarországra, azért nagyon szükölnék, ha nem bírnék menni, de hát az ugyanilyen fontos, hogy visszajöhessek". Élete középpontja azonban szülővárosa, Temerin, ahol gyerekkora óta lakik; „örök életemre ide rögzültem”.

Pries a transznacionális vagy transzmigráns ideáltípusát jellemezve arról beszél, hogy ők jellemzően nem tudják, akarják megnevezni életük középpontját, egyszerre kötődnek két világhoz, azaz itt is, ott is otthon(osan) érzik magukat. A transzmigránsok arra a kérdésre, hogy végső soron hol van az otthonuk, hová kötődnek, úgy válaszolnak: is-is (Pries 2010, 67.). Esetünkben ehhez legközelebb azok az értelmiségiek állnak, akik két világ intellektuális, társadalmi, intézményi, politikai rendszerébe ágyazottan élnek, két országban dolgoznak, rendelkeznek ingatlannal, bankszámlával.

A visszatérő migránsok ideáltípusával kapcsolatban említett, multinacionális cégnél betanított munkásként dolgozó, munkásszállón élő asszony a magyarországi világhoz lényegében munka- és lakótársai révén kötődik, velük tölti a szabadidejét is, együtt járnak kirándulni, ruccannak be Budapestre. Ő a migráció kényszerű voltát hangsúlyozza, és veszteségként éli meg, hogy amióta csak havonta jár haza, megritkultak, meggyengültek otthoni kapcsolatai, esetében az „itt is, ott is" lenni az ,itt sem, ott sem” élményévé alakult. ${ }^{25}$ Vele szemben azok a transznacionális migránsok ideáltípusához legközelebb álló értelmiségiek, akik szerbiai, magyarországi egyetemeken egyaránt oktatnak, két ország szellemi és közéletében vesznek részt, nyereségként élik meg kettős beágyazódásukat, hiszen két világban mozognak otthonosan. ${ }^{26}$

Azt mondhatjuk tehát, hogy az ideáltipikus transzmigráns priesi alakjával ritkán találkozhatunk kutatási terepünkön, azt viszont bizton állíthatjuk, hogy tetten érhetők azok a migrációs gyakorlatok, kapcsolatok, kötődések és identitások, amelyek a transznacionális teret meg- és folyamatosan újrateremtik, illetve amelyek gazdag leírását megtalálhatjuk a transznacionalizmus irodalmában.

E fejezetet lezárásaként a migrációs stratégiák és élethelyzetek változását, az egyes migrációs típusok közötti határok képlékenységét a székelyföldi vendégmunkások példáján mutatjuk be. Míg a magyarországi munkavállalás a kilencvenes években a megélhetési, boldogulási lehetőségek hiányára adott különleges, ritualizált, a helyi közösség előtt indoklásra szoruló válaszlépés 
volt, addig az ezredfordulót követően már elfogadott, magyarázatot és legitimációt nem igénylő egyéni és családi döntéssé, gyakorlattá vált. Húsz évvel ezelőtt a vendégmunkások még radikálisan elválasztották egymástól az otthoni és az idegennek tekintett magyarországi világot, mára azonban mindkét világban otthonosan mozognak, és itt is, ott is otthon érzik magukat (lásd Bodó 2008 tanulmányait). A fiatal széki vendégmunkások esetében pedig „a migrációs ido"szak várható befejezése és a végleges hazatérés ideje kitolódott a bizonytalan jövőbe. A korábban „kitérőként” meghatározott migrációs életciklus így az életút foáramába kerül, és a lehetőségek szempontjából több irányba is nyitottá válik" (Pulay 2005, 151.). Néhány szerző e változásokat a transznacionális migráció elméletébe és fogalmaiba ágyazva értelmezi (Bodó 2008).

\section{Az etnikai migrációról}

A transznacionális migráció fogalmi készlete és szemlélete, a priesi tipológia egy lehetséges értelmezési keretet kínál, mindenekelött a migráció dinamikájáról és a migránsok transznacionálisnak nevezhető gyakorlatairól, kötődéseiről. Abban azonban nem nyújt segítséget, hogy megértsük, kik is azok, akik vándorolnak. Az általunk vizsgált migráció sajátossága ugyanis, hogy határon túli kisebbségi magyarok érkeztek és érkeznek Magyarországra, illetve a volt Jugoszlávia köztársaságaiból kisebbségi(vé vált) szerbek menekültek a kialakuló szerb nemzetállam területére. A környező országokból Magyarországra irányuló vándorlás Gödri megfogalmazása szerint „valahol a belföldi és a nemzetközi migráció között helyezheto el, egy sajátos értelmezési keretben, amely figyelembe veszi a közös történelmi gyökerek, az etnikai identitás, a nyelvi azonosság, és a kulturális közelség szerepét az egész folyamatban" (Gödri 2005, 79.). Ez a migráció ugyan országhatárok átlépésével jár, de „a befogadó és a kibocsátó népesség ugyanahhoz a nemzethez tartozik, a bevándorlók - nyelvi és kulturális szempontból - nem egy idegen országba, hanem a saját hazájuknak tekintett »anyaországba« érkeznek, és a migráció számukra (az előző szempontokból legalábbis) nem kisebbségi státuszba kerülést a fogadó országban, hanem éppen a kibocsátó országbeli kisebbségi státuszból való kilépést eredményez" (Gödri 2010, 91.). Feischmidt és Zakariás nyomán pedig úgy fogalmazhatunk, hogy ha a migráció maga transznacionális térben zajlik is, illetve transznacionális teret hoz létre, maguk a migránsok gyakran az etnicitás kategóriáiban mesélik el és értelmezik történetüket. Az általunk vizsgált migrációs folyamatokban tehát az etnicitást „strukturális tényezoként” és a migráns tapasztalatok értelmezési kereteként egyaránt figyelembe kell vennünk (Feischmidt, Zakariás 2010, 153.). Az etnikai migráció, illetve az etnicitás migrációs folyamatokban játszott szerepének legfontosabb értelmezési lehetőségeiről Feischmidt és Zakariás (2010) tanulmánya nyújt átfogó, alapos áttekintést, elemzést. E munkára támaszkodva röviden bemutatjuk a különböző megközelítéseket, továbbra is arra törekedve, hogy ezek fényében saját kutatási tapasztalatainkat is értelmezzük. 
Az etnikai hazatérö/visszatérő migráció (return migration) az anyaország és a hozzá származás, nyelv, kultúra, vallás mentén kötődő diaszpóra viszonyában nyer jelentést. Izrael és Németország a diaszpóra-, illetve nemzetpolitika etnikai hazatérő migrációra gyakorolt hatásának leggyakrabban tárgyalt és ismert példái, e két állam aktívan támogatja a határain kívül élö, idegen állampolgárságú nemzettársak (co-ethnics) hazatelepedését. Abban egyetértés mutatkozik, hogy a környező országokból Magyarországra vándorló magyarok helyzete sajátos, részben történeti okokból - Trianon nyomán a határok változtak, nem az emberek hagyták el az országot -, részben abból fakadóan, hogy Magyarországra soha nem volt jellemző az a fajta, az anyaországba való áttelepedést egyértelműen támogató politika, mint például a fent említett két államban. A határon túli magyarokkal kapcsolatos politikák és politikai diskurzusok arra helyezték a hangsúlyt, hogy a kisebbségieknek a szülöföldjükön kell boldogulniuk, ott kell megőrizniük nemzeti identitásukat. Ebből fakad az, hogy a különböző magyarországi kormányok „sem a már Magyarországon tartózkodók automatikus befogadását, sem a határon túli magyarok kedvezményes állampolgársághoz jutását" nem támogatták (Zombory 2011, 220.). ${ }^{27}$ Másként fogalmazva, a határon túli magyarok Magyarországra vándorlásának forrása nem a nemzet- és migrációs politika vidékén keresendő (Feischmidt, Zakariás 2010; Gödri 2010).

A Temerinben letelepedett boszniai és horvátországi szerb menekültek a beszélgetések során ugyan nem használták az „,anyaország” fogalmát, de történeteikben egy markáns anyaországképet jelenítettek meg akkor, amikor a számukra menedéket, biztonságot, támogatást és erős nemzeti identitást nyújtó szerb államról, nemzetről beszéltek, ahol új otthonra találtak. Kevés olyan vajdasági migránssal találkoztunk, aki a maga vándorlását az anyaországba való hazatérésként beszélte el (lásd Olivér történetét Váradi 2013 tanulmányában), ugyanakkor a migránsok döntéseiben az őket az anyaországhoz füző kulturális, nyelvi és erős érzelmi kötelékek, esetleg családi kapcsolatok, képzetek és elvárások meghatározó szerepet játszottak. Magától értetődő volt számukra, hogy Magyarországra jöttek, s nem mentek tovább egy harmadik országba, ahol ismét csak kisebbségiek lehetnének; nem is gondoltak arra, hogy másutt is tanulhatnának. ${ }^{28}$

$\mathrm{Az}$ etnikai migráció alapvetóen gazdasági értelmezése szerint a migráció az egyes országok munkaerő-piaci különbségeiből, a megélhetés, boldogulás és mobilitás eltérő lehetőségeiből fakad; a kisebbségi sorban élő emberek azért indulnak útnak az anyaországba, hogy jobb életkörülmények közé kerüljenek, jobban fizetett munkához, karrierlehetőséghez jussanak. Az etnicitás, a nyelvi, kulturális hasonlóság ebben az esetben a munkaerőpiacon konvertálható társadalmi és szimbolikus tőkeként működik; magyar anyanyelvűek lévén nem voltak nyelvi hátrányban a munkaerőpiacon, illetve voltak, akik a velük szemben táplált szolidaritásból, szimpátiából alkalmazták őket. A szomszédos államokban élő magyarok magyarországi migrációjának vizsgálatakor kézenfekvő ez a megközelítés és értelmezés, tekintettel arra, hogy a hazánkban dolgozó külföldi munkavállalók többsége a környező országokból érkezett; ők lehetnek multinacionális 
cégek betanított munkásai éppen úgy, mint mezőgazdasági idénymunkások, építőipari vendégmunkások vagy budapesti polgári otthonokban dolgozó „háztartási bérmunkások" (utóbbihoz lásd például Bondár 2005). Ami a vajdasági magyar migránsokat illeti, nyilvánvaló, hogy akár a magyarországi munkavállalás (amelyről a megelőző fejezetben is szó esett), akár a tanulmányi célú migráció esetében (Erőss, Filep, Rácz, Tátrai, Váradi, Wastl-Walter 2011a, 2011b; Takács, Tátrai, Erőss 2013) a migrációs döntéseket megelőzi a két országban kínált gazdasági lehetőségek, mobilitási és boldogulási perspektívák összevetése. A Temerinben élő szerb menekültek között azok, akik először egy másik vajdasági településen próbáltak megkapaszkodni, később a város kedvező közlekedési helyzete, az Újvidék közelségéből fakadó elhelyezkedési lehetőségek miatt költöztek ide. Ám még azok is említik ezeket a szempontokat a letelepedés mellett szóló érvek között, akik már az első hullámban érkeztek Temerinbe; itt lakó rokonaiktól rendelkeztek információkkal a munka- és megélhetési lehetőségekről. Úgy is fogalmazhatunk, hogy a migráció egyszerre etnikai és gazdasági meghatározottságú folyamat (Gödri 2004), a migrációs történetekben jellemzően elválaszthatatlanul összefonódnak a döntések hátterében meghúzódó etnikai és gazdasági motívumok, illetve hogy a „migránsok etnicitással kapcsolatos tapasztalatai és egyúttal gazdasági törekvései is a migráció folyamatában bontakoznak ki, annak során változnak, alakulnak" (Pulay 2005, 147.).

Az etnikai migráció szúkebb értelmezésében (Pulay 2005, 146.) a hangsúly a migrációt kiváltó taszító tényezőkre kerül. Eszerint a kisebbségi sorban elszenvedett megkülönböztetés, esetleg üldöztetés és az ebből fakadó félelem áll az anyaországba való vándorlás hátterében, esetleg az, hogy a kisebbség tagjai csak gyengén ágyazódnak be a többségi társadalomba. A horvátországi és boszniai szerb menekültek a háború során szerb mivoltuk miatt kerültek életveszélybe, kényszerü migrációjuk minden kétséget kizáróan etnicitásukhoz köthető. A vajdasági magyar migránsok történeteiben is a háborúhoz kapcsolódik a fenyegetettség, félelem élménye, mindenekelött a behívóktól való félelemhez. Ugyan a Vajdaság maga nem volt háborús események színhelye s a háború nem a magyarok ellen folyt, a nacionalizmus egyre éleződő légkörében egyre nehezebb volt kisebbségiként élni. Hallottunk történetet a magyar újságírót fenyegető névtelen szerb telefonálókról, arról, hogy az iskolai ebédlőben miként kezdtek egyszer csak a magyaroktól félrehúzódni, elkülönülni a szerb kollégák, arról, hogy az egyetemen egyre elviselhetetlenebbé vált a magyarokkal szemben is ellenséges, gyanakvó légkör. A vegyes házasságokban élőknek sem volt könnyü a helyzetük: aki szerb létére magyar férfit választott, gyakran hallhatta, miért nem volt neki elég jó egy szerb férj; az ilyen házaspárok társaságából el is maradoztak jó páran. Többen annak a meggyőződésüknek is hangot adtak, hogy a magyar fiatalokat a létszámukhoz képest nagyobb számban hívták be „ágyútölteléknek”, s hogy a vajdasági magyar politikában aktív szereplők kapták meg (volna, ha átveszik) az elsők között a behívóikat. Az etnicitás, a kisebbségi helyzet tehát - ha nem is úgy és olyan tragikus módon, mint a harcok és az etnikai tisztogatás elől menekülő horvátországi és boszniai szerbek esetében - 
szerepet játszott a vajdasági magyarok kényszermigrációjában is; kisebbségiként elszenvedői voltak a nacionalizmusnak, és nem akartak közösséget vállalni a „nagy nemzetek” háborúival. A vajdasági magyar migránsok elbeszélései rejtettebben, míg a temerini szerb menekültek történetei közvetlenül alátámasztják azon megközelítés érvényességét, amely a „kényszermigrációt a nemzeti hovatartozást kikezdő és provokáló jelenségként" kezeli, olyan migrációként, amely „a nemzetállami területi norma alkalmazásának a következménye, amelyre reakcióként az egyén arra kényszerül, hogy újraalkossa, helyrehozza, fenntartsa nemzeti identitását" (Zombory 2011, 150.).

A többségi társadalomba való gyenge integráltság is lehet a migrációt kiváltó tényező. A Magyarországra irányuló oktatási célú migráció hátterében több olyan, akár a végleges elvándorlást tápláló tényező áll, amely e megközelítés keretében értelmezhető: a szerb államnyelv elégtelen ismerete, a magyar anyanyelvű diákok számára magyar nyelven elérhető képzések szűkössége, a magyarországi diplomák honosításának bürokratikus és lassú rendje (lásd ehhez Takács, Tátrai, Erőss 2013 tanulmányát ebben a számban). Több beszélgetőtársunktól hallhattunk arról, hogy kisebbségiként „mindig is” nehezebb volt boldogulni, a vezető pozíciókba mindig a többségi nemzet tagjai kerültek, s hogy magyarként mindig többet és jobban kellett ahhoz dolgozni, hogy a többségi társadalom elismerje teljesítményüket. Általánosnak mondható tapasztalat és vélemény, hogy a Vajdaság etnikai szerkezetének átalakulásával, a szerb nemzetiségű lakosok többségbe kerülésével nehezebb lett az elhelyezkedés, néhányan etnikai szempontú munkaerő-piaci megkülönböztetésről beszéltek (lásd ehhez például Erőss, Váradi 2013 írását a Temerini mozaik blokkban). Kutatási tapasztalataink is megerősítik azt az állítást, hogy a társadalmi mobilitás útjai, különböző időszakokban ugyan eltérő mértékben, de mindvégig korlátozottak voltak a kisebbségi magyarok számára a környező országok többségi társadalmaiban (Gödri 2010, 92.).

Az etnicitás migrációban játszott szerepének mindhárom vázolt magyarázó modellje alkalmas a migrációt kiváltó és mozgató okok elemzésére, a migráns narratívák értelmezésére. Azt azonban nem állíthatjuk, hogy bármelyikük kizárólagos érvényre tehet szert, még a háború kiváltotta kényszermigráció esetében is láthatjuk a gazdasági megfontolások nyomait például az új lakóhely megválasztásában. Az etnicitáshoz kapcsolódó gazdasági, kulturális, érzelmi, erkölcsi vonzó és taszító tényezők a migránsok történeteiben is elválaszthatatlanok egymástól, s korántsem állandóak, a migráció folyamatában is változnak, különböző súllyal és értelmező erővel bírnak. Ugyanakkor, még ha - mint a magyarországi vendégmunka vagy továbbtanulás esetében - a boldogulással, mobilitással összefüggő elvárások, illetve a Szerbia és Magyarország közötti gazdasági különbségek a migráció alapvető kiváltó okai is, az etnicitás, a nyelvi és kulturális kötődés, a kisebbségi helyzet, az identitás fontos szerepet játszanak a migrációs döntésben, a vándorlásban, a befogadó országban való boldogulásban, beágyazódásban. Mindezek alapján, más magyarországi kutatókhoz 
hasonlóan, Rogers Brubaker meghatározását tartjuk a leginkább gyümölcsözőnek, aki az etnikai migráció tág értelmezését használva minden olyan vándorlási folyamatot etnikai migrációnak tekint, amelyben az etnicitás kulturális és szimbolikus tőkeként szabályozó szerepet játszik (Brubaker 1998; Feischmidt, Zakariás 2010; Gödri 2010; Pulay 2005, lásd még e számban Tátrai, Kocsis, Gábrity Molnár, Takács 2013 tanulmányát).

\section{Néhány szó a boldogulásról}

A temerini menekültek történeteinek közös vonása az erős nemzeti identitás, az új hazához való kötődés megvallása. Abban már eltérnek az életutak, hogy ki-ki hogyan boldogult új otthonában; van, aki megélhetési gondokról beszélt, mások sikeresen megkapaszkodtak, családi vagy alkalmazottakat is foglalkoztató vállalkozók lettek, új szolgáltatásokkal jelentek meg a helyi piacon/piactéren. A vajdasági magyar migránsok túlnyomó többsége otthonra talált és otthon is érzi magát Magyarországon, boldogult, sikerrel folytatta vagy építette újra egzisztenciáját. Tudjuk, hogy a hólabdamódszer miatt ez a kép torzíthat, hiszen vélhetően többnyire azok vállalkoztak beszélgetésre, akik elégedettek jelenlegi életükkel. Ezt a feltételezést közvetett módon maguk a migránsok is megerősítették azzal, ahogy - ha ez szóba került - a szülőföldjükre visszatért vajdasági magyarokról beszéltek: azok mentek haza, akik nem találták fel magukat, nem tudtak alkalmazkodni a megváltozott körülményekhez. Ez az értelmezés implicit módon kudarcnak tekinti a visszatérést.

Az általunk megismert vajdasági migránsok körében a magasan kvalifikáltak és a vállalkozók felülreprezentáltak. Ez nem feltétlenül azt jelenti, hogy a beszélgetések idején mindannyian bejegyzett céggel, üzleti vállalkozással rendelkeztek, de azt igen, hogy áttelepedésük után egy ideig valamilyen vállalkozást működtettek. Az esetek jelentős részében a vállalkozóvá válást a jogi környezet kényszerítette ki; a legkülönfélébb szakmai hátterü, iskolai végzettségű migránsok minimális tőkével hoztak létre vállalkozásokat, ezzel igazolták a hatóságoknak, hogy magyarországi megélhetésüket biztosítani tudják. Ez ugyanis a tartózkodási engedély feltétele volt, s alkalmazottként nehezebben tudtak elhelyezkedni. Ezek a kényszervállalkozások ma legfeljebb papíron léteznek. Mások azonban korábbi tevékenységüket folytatták vállalkozásként vagy vágtak bele Magyarországon új tevékenységbe. A kilencvenes évek elején Szegeden megjelent a "menekülő tőke” (Szónokyné 1997), jugoszláv állampolgárok sora hozott létre vállalkozást, fektetett be a városban és a határrégióban. Egyes becslések szerint a kilencvenes évek derekán egyedül Szegeden kétezer vajdasági gyökerű vállalkozás működött, több mint 400 milliárd forintos össztőkével (Végel 1996). Mi a beszélgetések során nemigen hallottunk s nem is kérdeztünk Magyarországra menekített és itt befektetett pénzeszközökről, a 
vállalkozások anyagi hátteréről. Az általunk megismert szegedi vállalkozók az építőiparban vagy a kereskedelemben és a szolgáltatásokban dolgoztak, és jellemzően önfoglalkoztatóak, legfeljebb egy-két alkalmazottal. Van közöttük, aki németországi vendégmunka során megtakarított pénzével indította újra stabil vállalkozását, mások először magyarországi vállalkozó mellett, alkalmazottként dolgoztak s csak néhány év után önállósították magukat. A vajdasági magyar migráns vállalkozók között kevesen működnek a hagyományos termelő ágazatokban. Mi az építőipari vállalkozók mellett mindössze egyetlen olyan családdal találkoztunk, amely egy baranyai faluban közel húsz év alatt virágzó, uniós támogatásokkal fejlesztett farmgazdaságot épített fel. ők azért telepedtek Magyarországra, mert a rendkívül olcsón megszerezhető kárpótlási jegyekkel jelentős birtokot tudtak itt megalapozni. A gyerekek időközben felnőttek, családot alapítottak, a legidősebb visszament a Vajdaságba, ott gazdálkodik s viszi tovább a több lábon álló gazdaság mezőgazdasági gépkereskedelmi ágát, a másik kettő Magyarországon él, könyvelőként és gazdálkodóként kapcsolódik a kiterjedt családi vállalkozáshoz.

A kutatásban résztvevő kolléganőnk, Rácz Katalin (Rácz 2012) egy előadásában a Magyarországon élő vajdasági magyarok vállalkozásait több szempontból vizsgálta. A következőkben előadásának tanulságait foglaljuk össze röviden. A vállalkozók jellemzően több lábon állnak, sokféle tevékenységet folytatnak; említhetjük a pszichológust, aki sporteszközöket gyárt, az építőipari reklámfilmeket gyártó és nyomdászati szolgáltatásokat nyújtó vállalkozót, a zeneszerző újságírót, aki tolmácsként és fordítóként is dolgozik vagy az orvost, aki kórházi praxisa mellett különleges akvarisztikai vállalkozást indított. Ezek a vállalkozók jellemzően önfoglalkoztatáson, öngondoskodáson alapuló megélhetési mintát követnek, ha alkalmaznak idegen munkaerőt, akkor azok gyakran vajdaságiak ${ }^{29}$ vagy más, határon túli magyarok. Ez részben a szolidaritással magyarázható, részben azzal, hogy az anyaországbeli magyarok munkakultúrájával többen is elégedetlenek voltak. Egyikük csak „óranéző” munkaerőnek nevezte a magyarországiakat, akik alig várják, hogy leteljen a munkaido", nem elég képzettek és nem igényesek a minőségre. Közös jellemzője e vállalkozóknak a feszített munkatempó, az önkizsákmányoló életforma, ami részben egzisztenciájuk újraépítésének felhajtóerejéből fakad, részben az otthonról hozott munkakultúrával, szokásrendszerrel magyarázható. E vállalkozásoknak Magyarországon nehézségekkel is szembesülniük kellett. Ezek részben anyagi természetủek voltak: nehezen jutottak hitelekhez, fejlesztési forrásokhoz, nem voltak saját forrásaik, a Szerbiában maradt vagyont nem tudták mobilizálni stb. Legalább ugyanekkora súllyal esett azonban latba, hogy nem rendelkeztek olyan magyarországi kapcsolatokkal, amelyeket az üzleti életben tőkeként mobilizálni tudtak volna s hogy nem voltak beágyazódva a vállalkozásukat körbevevő nyelvi és kulturális környezetbe. Egy vállalkozónak azt tanácsolta egyik ismerőse, hogy ha tárgyalni megy, ne árulja el, honnan jött, ha akcentusa miatt mégis megkérdeznék, mondja azt, hogy dunántúli. ő pedig az első években igyekezett „pestiesen” be- 
szélni, így is előfordult azonban, hogy „kinézték” ${ }^{30} \mathrm{Mi}$ az, amire ezek a vállalkozók támaszkodhattak, amit erőforrásként tudtak mobilizálni? Elsősorban a tudásuk, ami gyakran felsőfokú végzettséget, magas szintű szaktudást, otthonról hozott munkatapasztalatot egyaránt jelent. Nyitottak az új, innovatív megoldásokra, rugalmasan tudnak alkalmazkodni a mindenkori lehetőségekhez, nagy munkabírással jellemezhetők, emellett vajdasági hátterükből fakadóan jártasan és könnyen mozognak kultúrák között (Rácz 2012). A kultúrák és nyelvek közötti mozgásban való jártasság teszi lehetővé néhány vállalkozó számára, hogy a jugoszláv utódállamokban müködő cégekkel aktív és gyümölcsöző piaci kapcsolatot alakítson ki.

A vajdasági vállalkozók baj esetén, válsághelyzetben ,átmentett” családi, rokoni, baráti kapcsolataikra támaszkodhattak (Rácz 2012). Egyik interjúpartnerünk, aki egy budapesti székhelyü, vajdasági tulajdonban lévő kereskedelmi cégnél dolgozik pénzügyi vezetőként, beszámolt a vajdaságiak üzleti kapcsolatait jellemző „rettentő összetartozásról”, ami egyrészt kölcsönös segítségen alapuló hálózatot, információkat, megrendeléseket, közvetítést jelent, másrészt egyfajta üzleti stílust. Az elhúzódó anyagi természetű vita könnyen lezárul, ha kiderül, hogy a partner maga is vajdasági, „teljesen megváltozott a viszonyuk onnantól kezdve, hogy megtudták, hogy mind a ketten vajdaságiak. Egy közvetlenebb kapcsolat alakult ki, egy nyiltabb vagy lazább. Bizalmilag más." A bizalom a közös múltból, háttérből és nyelvből fakad, adott esetben a Németországban élő szerb üzletemberrel szemben is működik, „tehát olyan bizalommal vannak egymás iránt, hogy ja, hát te is ott éltél, én is ott éltem" (Jugoszláviában). ${ }^{31} \mathrm{~A}$ bizalom mint az üzleti kapcsolatok sarokköve más összefüggésben is fölmerült, amikor vajdaságiak arról panaszkodtak, hogy magyarországi partnerek becsapták őket, és szembeállították egymással a vajdasági világot a magyarországival: míg ott elég volt a becsületszó és a kézfogás, itt hiába rögzítik papíron a megállapodást, azt nem tartják be.

\section{Otthonok}

Temerin és Szerbia támogatást, menedéket, új otthont nyújtott a horvátországi, boszniai menekült szerbeknek, akiknek egy része több-kevesebb rendszerességgel kapcsolatot ápol a szülőföldjükön maradott vagy oda visszatért rokonaival, ismerőseivel. A látogatásokat azonban nemegyszer a félelem és a veszteség érzése kíséri. Mások pedig megszakítottak minden kapcsolatot szülőföldjükkel a háború, a kényszerű migráció radikálisan átalakította a kötődések, lojalitások rendszerét (lásd Ristić, Nagy, Kicošev 2013a írását a Temerini mozaik blokkban). Magyarországon talán csak egyetlen olyan vajdaságival találkoztunk, aki tudatosan megszakított minden kapcsolatot szülőföldjével s egyáltalán nem látogat haza. Arra már inkább van példa, hogy a családtagok, ismerősök, barátok maguk is átjöttek Magyarországra, az idős szülők meghaltak, így lazultak meg vagy 
foszlottak szét a migránsokat a szülőföldhöz kötő szálak, a hazautak a temetőlátogatásra korlátozódnak. Amikor vajdasági utazásaikról beszélnek, a legtöbben így fogalmaznak: ,megyek haza és jövök haza”, a jelenlegi és a régi otthonhoz egyaránt kötődnek. Milyenek ezek az otthonok?

„Emigráltam az anyaországba” - fogalmazott egy Budapesten élő vajdasági író, s ez a mondat nemcsak a kényszerű migrációra utal, hanem arra a sajátos viszonyra is, amely a Jugoszláviában felnőtt, életük rövidebb-hosszabb idejét ott töltő beszélgetőtársainkat (legalábbis egy részüket) az anyaországhoz füzte. A kulturális kötődés erős és intenzív volt, Magyarországról magyar nyelvủ könyveket hordtak haza, s egy temerini beszélgetőtársunk felidézte, hogy milyen szomjas kíváncsisággal, kitüntető figyelemmel és örömmel fogadta a helyi magyar közösség az új magyar filmeket, a városba látogató budapesti színművészeket, hírességeket. A kapcsolatok nem csak egyirányúak voltak. Az Új Symposion rendszeresen közölte magyarországi írók és költők műveit, ők gyakori látogatók voltak Újvidéken. Nemegyszer hallottunk arról, mennyire fontosnak tartották a családok, hogy a gyerekek is megismerjék az anyaországot, nyaranta meglátogatták egy-egy vidékét. Az akkori gyerekek visszatekintve az élmények mellett azt is megemlítették, hogy Magyarországot szürkének, kopottnak, szegénynek látták. Olcsó volt, ahol 100 német márkából nem csak 40-50 könyvet vásárolhatott az ember, hanem a Gellért Hotelben lakhatott. Üzletelni is lehetett. A temerini kézilabdacsapat buszát a határátkelőn várták már az áthozott konyakért, Vegetáért, a közlekedési rendőr lekenyerezhető volt egy csomag rágógumival, a butikokban eladott nyugati lemezek árából finanszírozható volt a balatoni nyaralás. A jugoszláviai jólét, fogyasztási színvonal és utazási szabadság egyfajta fölényérzetet táplálhatott az anyaországiakkal szemben. Ironikusan emlékezett erre egy Budapesten élő művészeti menedzser, felidézve, hogy Adidas-cipőjüket a lábukról vették volna meg a „hülye magyarok". Aztán a kilencvenes években megérkeztek Magyarországra a vajdasági menekültek, „és mi lettünk a hülyék”.

Az anyaországban meggyökeresedtek, otthonra találtak. ${ }^{32}$ Ennek ellenére majd' mindenki megtapasztalhatta, hasonlóan az erdélyi migránsokhoz, hogy mit is jelent a „szimbolikus befogadás és gyakorlati kirekesztés ellentmondása” (Feischmidt 2005, 17.). A helyzetük legalizálását, rendezését nehezíto”, olykor megalázó „,hivatali packázásról" - mint például az egy időben kötelező állampolgársági vizsga, az AIDS-teszt, vagy a szerbről magyarra fordítás közben megváltozó nevek esetei -, a munkavállaláshoz, tartózkodáshoz szükséges papírok beszerzésének, vajdasági kifejezéssel „papírizáció" nehézségeiről sok történetet hallottunk. Többszöri migrációjának, a menekült státus majd letelepedési és munkavállalási engedély megszerzése érdekében folytatott groteszkbe forduló történetét álnéven meg is írta egy vajdasági migráns (Pannonymus 2007). Azt is tapasztalhattuk, hogy a gyakran évekig elhúzódó hivatalos ügyintézés erősítheti a hivatalnokok megvesztegethetőségének gyanúját és a különböző migráns csoportokkal szembeni elöítéleteket; többen is említették a „kínaiakat”, akik soron kívül, ügyvédekkel, pénzzel felszerelkezve, hamarabb jutottak papírokhoz, mint a határon túli magyarok (Feischmidt, Zakariás 2010; Melegh, Molodikova 2009). 
Ahogy a mindennapi találkozásokban, hivatalokban, diskurzusokban az erdélyi vendégmunkásokra vagy áttelepült diplomásokra könnyen rákerülhet a „román stigma” (Feischmidt 2004, 2005; Fox 2005; Pulay 2005; Zakariás 2008), úgy nem egy vajdasági magyar migráns megkapta különböző helyzetekben az idegenellenességből és tudatlanságból fakadó „,szerb” vagy „,jugó” jelzőt. ${ }^{33}$ A 2004-es népszavazás fiaskóját pedig arculcsapásként élték meg az itt élő vajdaságiak is. A migráns erdélyi magyarok az őket a munkaerőpiacon, hivatalos eljárások, mindennapi találkozások során vagy a népszavazást övező diskurzusokban érő sérelmeket gyakran magyarságuk megkérdőjelezéseként élik meg, amelyre válaszul a jobb, „igazibb” magyarság narratíváját adják, amelyben az erdélyiek, a székelyek, a határon túliak a magyar kultúra és értékek igazi hordozóiként jelennek meg, szemben a magyarországiakkal (Feischmidt, Zakariás 2010; Fox 2005; Pulay 2005; Zakariás 2008). A vajdasági magyar migránsokkal folytatott beszélgetésekben ha volt is, aki csalódottságnak adott hangot: „ott nem kellettem a szerbeknek, itt nem kellettem a magyaroknak" -, mi nem találkoztunk sem a kettős kisebbségi helyzetre reflektáló „sérelmi narratívával” (Zakariás 2008), sem az igazibb magyar narratívájával. Ha összehasonlításra kerül sor, akkor a vajdasági magyarok is osztoznak a magyarországi esszencializáló diskurzusban, amely az erdélyi magyarságot értékesebbnek, az autentikus magyar kultúra forrásának tekinti (Pulay 2005; Zakariás 2008; Zombory 2011), mondván, a magyarok „csak” a török uralom után telepedtek meg a Vajdaságban.

A beszélgetések során a vajdaságiak az őket a magyarországiaktól elválasztó szimbolikus határvonalakat a vajdasági identitást bemutató narratívákban jelenítették meg, amelyek elsősorban a mentalitás, az életvitel, az értékek különbségei köré szövődtek. Beszélgetőpartnereink a vajdaságiakat nyíltnak, őszintének, temperamentumosnak, lazának, vendégszeretőnek stb. írták le, a magyarországiakat ezzel szemben őszintétlennek, bizalmatlannak, önsajnálatra hajlamosnak, magukba fordulóknak, bezárkózónak, individualistának, anyagiasnak stb. tartották. E tematikus szám egyik tanulmánya címében utal a vajdasági identitás kettőségére: „kulturálisan magyarok, mentalitásban szerbek vagyunk”. Ebben az identitáskonstrukcióban a vajdaságiak „déli” vagy „,balkáni” vonásai, mint a vendégszeretet, temperamentum, lazaság, olyan értékként jelennek meg, amelyeket a multikulturális környezetben, más - elsősorban a szerb - nemzetiségü szomszédaiktól vettek át, akaratlanul is, az együttélés során. E narratívákban a vajdasági magyarok valahol a magyarországiak és a déliek/balkániak között helyezik el magukat, s e köztes helyzetből, a két kultúra, mentalitás találkozásából született az egyedi identitás, amelynek fontos eleme a tolerancia más kisebbségekkel szemben (lásd részletesebben Váradi, Erőss 2013 tanulmányát e számban).

A határon túlról érkezett magyar bevándorlók nemzeti identitását a szülőföldhöz (Erdély, Felvidék, Kárpátalja, Vajdaság) való erős kötődés, ezzel szemben a kibocsátó országhoz való kötődés elutasítása jellemzi (Gödri 2010, 108-109.). Az általunk megkérdezett vajdasági magyar migránsok esetében is azt láthattuk, Szerbiához nem füzi őket semmiféle lojalitás, érzelmi kötődés, azt nem tekintik 
hazájuknak. Az idősebbek közül néhányan jugoszláviai magyarnak (is) vallották magukat, vagy mert Jugoszláviában töltötték gyermekkorukat, fiatalságukat, életük hosszabb-rövidebb részét, vagy mert valóban szerettek ott élni, ,jó volt jugoszlávnak lenni" a háború előtt. Többségüket a Vajdasághoz, ezen belül pedig a szülőfalujukhoz, szülővárosukhoz füzik szoros érzelmi kötelékek. ${ }^{34}$ A vajdasági otthon kétféle módon jelenik meg a migráns narratívákban. A történetek egyfelől a természethez, a családi házhoz, az emberekhez, a miliőhöz, a hangulatokhoz és élményekhez való erős ragaszkodásról, illetve ezek emlékezetéről, másfelől a vajdasági otthon radikális átalakulásáról szólnak. Majd' minden migráns beszélt arról - ki fájdalommal, ki rezignáltan, ki dühösen -, mennyire megváltozott az otthonuk világa. Mind kevesebben vannak a magyarok s mind többen a szerbek, akik a maguk képére formálják a településeket, birtokba veszik a nyilvános tereket; az utcán, kávéházakban, üzletekben egyre ritkább a magyar szó; Újvidék, Szabadka elveszíti monarchiabeli arculatát, történetét, és balkáni várossá válik.

\section{Tartalom és köszönetnyilvánítás}

A Tátrai, Kocsis, Gábrity Molnár és Takács által jegyzett tanulmány összefoglaló történeti, földrajzi, demográfiai áttekintést nyújt a Vajdaságot érintő belföldi és nemzetközi migrációs folyamatokról. Az elemzés az elmúlt bő húsz évre fókuszál, ám bemutatja a történelmi előzményeket, érintve az 1918 előtti időket is. Az egyes, egymástól jól elhatárolható vándorlási korszakokban a politikai változások, háborúk által kikényszerített migráció, a gazdasági célú migráció és az etnikai migráció néha egyszerre hatottak, néha az egyik típusú vándorlás markánsabban jelentkezett. A szerzők hangsúlyozzák, hogy az etnicitás migrációban betöltött szerepe minden időszakban, napjainkig meghatározó; a határváltozások által generált kényszermigrációk, a szerb menekültek letelepedése a szerb nemzetállamban, a vajdasági magyarok Magyarországra vándorlása az etnikai migráció értelmezési keretében elemezhetőek. Az elmúlt húsz év migrációs folyamataiban az etnikai taszító és vonzó tényezők mellett azonban a gazdasági, fejlettségbeli különbségek is perdöntő szerepet játszottak.

Váradi és Erőss a vajdasági magyarok által szervezett budapesti ún. jugóbulik kapcsán a migráció, zene és identitás összefüggéseire mutat rá. A kibocsátó ország zenéje nemcsak a migrációval járó veszteségérzést csillapíthatja, hanem a maguk mögött hagyott világhoz tapadó emlékek, élmények felidézésével és újrateremtésével megerősítheti a migránsok identitását. A Balkán kulturális világának felidézésével a jugóbuli a résztvevő magyar migránsok számára olyan teret hoz létre, amelyben megélhetik identitásuk „déli” vonásait, és egyúttal a magyarországi magyaroktól is megkülönböztethetik magukat. A szerzők azt a kérdést is körbejárják, hogy a jugóbuli és a köré szerveződő narratívák értelmezhetőek-e az ún. jugónosztalgia mint politikai, kulturális jelenség keretein belül. 
A vajdasági magyar fiatalok tanulmányi célú migrációjával, jelentőségéből fakadóan, e számban két tanulmány is foglalkozik. Takács, Tátrai és Erőss a folyamatot a transznacionalizmus és az „agyelszívás” elméleti és szemléleti keretébe ágyazva elemzi. A tanulmányi célú migrációról elérhető adatok, a folyamatok dinamikájának, változásainak bemutatásán, a tanulmányi célú migrációs döntések hátterében álló taszító és vonzó tényezők számbavételén túl a tanulmány magyarországi és vajdasági nézőpontból is bemutatja e migrációs típussal járó nyereségeket és veszteségeket, s azokat a nemzetpolitikai törekvéseket, amelyek a folyamatot alakítani igyekeznek. Váradi másként közelít a tanulmányi célú migrációhoz. Azt vizsgálja, hogy a tanulmányi célú migrációról és a végleges át- vagy visszatelepedésről szóló döntések milyen narratívákba ágyazódva jelennek meg a vajdasági fiatalok elbeszéléseiben. A családorientált, a kisebbségi magyar identitás köré szerveződő, valamint az orientalista diskurzushoz kapcsolódó narratívák elemzése lehetőséget nyújt a migrációról szóló történetek, a migrációs döntések és a narratív identitás összefüggéseinek feltárására.

A migráció és a nyelv kapcsolatát járja körül Gábrity tanulmánya. A szerző abból indul ki, hogy a Magyarországra ingázó vajdasági magyarok nyelvi szempontból kettős kisebbségi helyzetben élnek. Míg Szerbiában az államnyelv mellett a magyar nyelv gyakran a privát szférába szorul vissza, addig Magyarországon a migránsok azzal szembesülnek, hogy a vajdasági nyelvváltozat több tekintetben is eltér a magyarországitól, s ezért idegennek, furcsának hathat, beszélöjét pedig könnyen azonosíthatóvá teszi. Az alapos elméleti áttekintés és az elemzés középpontjában a vajdasági magyar migránsok nyelvi identitása és az uralkodó nyelvi ideológiákhoz való viszonya áll.

A Temerini mozaik címet viselő blokk négy hosszabb-rövidebb írást tartalmaz, magyar és szerb szemszögből, különböző szemlélettel és változatos módszereket alkalmazva igyekszik feltárni az etnikai konfliktusokról ismert Temerin világát. Nagy és Tátrai bevezetőjükben korszakok szerint áttekintik a város lélekszámát és etnikai struktúráját befolyásoló legfontosabb migrációs folyamatokat. Temerin mezőgazdasági adottságainak, közlekedési fekvésének, Újvidék közelségének köszönhetően folyamatosan növelte népességét. A várost jellemző migrációs folyamatokat azonban a háborúk s következményeik, valamint azok a mindenkori állami politikák is erőteljesen befolyásolták, amelyek közös jellemzője a nemzetépítés és az etnikai homogenizációra való törekvés volt. A szerzők felteszik azt a kérdést is, hogy a migrációs folyamatok miként függenek össze az etnikai konfliktusokkal. A választ abban találják, hogy a város etnikai szerkezetének átalakulása rendkívül gyorsan ment végbe, ami alapvetően átalakította az interetnikus viszonyokat, etnikus hierarchiákat, hatalmi struktúrát és éles törésvonalakat hozott létre az immár kisebbségbe került magyarok, a városban régóta élő, valamint a menekült szerbek csoportjai között. Ristić, Nagy és Kicošev két tanulmányt is jegyeznek. Az egyik a Horvátországból és Boszniából érkezett szerb menekültekkel készített interjúk elemzésén alapszik. A háború, a kényszerű menekülés és az azt kísérő veszteségek a menekültek nemzeti identitá- 
sának erősödéséhez és az őket minden lehetséges eszközzel segítő szerb állam iránti mély lojalitáshoz, érzelmi kötődéshez vezettek. A szerb menekültek arról beszéltek, hogy úgy érzik, az „őslakosok” elfogadták őket és integrálódtak a helyi társadalomba, valamint szerbekhez és magyarokhoz kötődő jó kapcsolataikról számoltak be. A másik tanulmányban a szerzők egy szerb és magyar középiskolások körében végzett kérdőíves felmérés alapján arra keresik a választ, hogy a különböző helyek és terek, amelyekben a fiatalok élnek, amelyek körülveszik őket, s elsősorban a lakóhelyük, Temerin milyen módon alakítják identitásukat. Az eredmények azt mutatják, hogy a lokalitás ugyan jelentős szerepet játszik a fiatalok identitáskonstrukcióiban, ugyanakkor a megkérdezett diákokat a lokalitáshoz nem füzik erősebb kötelékek, mint a saját etnikai csoportjukhoz, illetve nemzetükhöz. Lokális identitásuk tehát nem erősebb, mint nemzeti, etnikai identitásuk. Szemben a békés együttélést, jó viszonyt hangsúlyozó szerb narratívákkal, a magyarok elbeszélései, ahogy ez Erőss és Váradi tanulmányából kiderül, erős, jószerivel áthághatatlan szimbolikus határokra utalnak, s az új „telepeseket” lényegében beilleszkedésre alkalmatlan és nem hajlandó homogén csoportként mutatják be. A szerb menekült és magyar szemszögbőll egymással szögesen ellentétes Temerin-kép bontakozik ki. A két helyi iskola magyar és szerb tanulói körében végzett mentális térképezés pedig arra mutatott rá, hogy a konfliktusok, az erőszak jelen van a leginkább érintett generáció mindennapjaiban, de a diákoknak csupán töredéke utalt a konfliktus etnikai jellegére.

Végezetül, de nem utolsósorban köszönetet kell mondanunk. Mindenekelőtt azoknak a vajdasági embereknek, éljenek bár otthon vagy Magyarországon, legyenek magyarok vagy szerbek, akik megtiszteltek bennünket bizalmukkal és elmesélték nekünk a történetüket. Köszönet illeti a Swiss National Science Foundationt (Svájci Nemzeti Tudományos Alap), amely nemcsak a kutatást, hanem e tematikus szám megjelenését is támogatta. Az Alap elvárta, hogy a projekt megvalósításában vegyenek részt fiatal kutatók, kapjanak lehetőséget arra, hogy e munka során is tanuljanak, fejlődjenek. Köszönetet mondunk fiatal kutatótársainknak, akik tanulmányok szerzőiként is megjelennek ebben a számban. Erőss Ágnes és Tátrai Patrik közreműködése, segítsége nélkül ez a tematikus szám nem jelenhetett volna meg. Pap Ágnest a szerbiai kollégák írásainak fordításáért, Thomas R. Richerst az angol nyelvű összefoglalók gondozásáért illeti köszönet. A Tér és Társadalom lektori anonimitásra vonatkozó szokásaival e tematikus szám erejéig szakítva, megköszönjük Gödri Irén és Nagy Teréz figyelmes, gondos és értő lektori munkáját.

\section{Jegyzetek}

1 A projekt száma: IZ73Z0_128097, időtartama 2010-2012.

2 A Magyarországon megkérdezett vajdasági migránsok jószerivel mindannyian (vajdasági vagy jelző nélküli) magyarnak tartották magukat. Interjút készítettünk azonban egy-két olyan emberrel, aki legalábbis a vándorlás idején nem magyar identitású volt. Példaként említhetjük azt az asszonyt, aki német-szerb családban született, férje magyar volt, ám a szerb 
volt a család nyelve. Az asszony volt az, aki a nacionalizmus és a háborúk hatására úgy döntött, hogy a családnak el kell hagynia Újvidéket, mondván, az az ország, amelyet ő szeretett, nincs többé. A legutóbbi magyarországi népszámlálás alkalmával magyarnak vallotta magát, szerb és német kötődéssel. Egy másik asszony pedig horvát-magyar családban született, de magyarul nem tudott, férje szerb volt, aki nem akart részt venni a háborúban, ezért elmenekültek Magyarországra.

3 Magyarországon 82 interjú készült vajdasági migránsokkal, az említett városok mellett Kiskunfélegyházán, Hódmezővásárhelyen, Kecskeméten, Pécsett, Veszprémben és néhány faluban. Ezen túlmenően tíz strukturált interjú készült Szegeden a Bevándorlási és Állampolgársági Hivatal, oktatási intézmények, kollégiumok vezetőivel, városi tisztviselőkkel és a szegedi szerb kisebbségi közösség képviselőivel. A Vajdaságban összesen 90 interjú készült migránsokkal, menekültekkel, a magyar-szerb határon ingázó vajdaságiakkal, ezen felül húsz különböző vajdasági és szegedi oktatási intézmény vezetőjével.

4 A vajdasági magyar író, Végel László nemrég megjelent naplóregényében olvashatunk arról, hogy a németországi vendégmunka a hatvanas évek közepétől miként változtatta meg a falusi fogyasztási és építkezési szokásokat, lakáskultúrát s nem utolsósorban a németekről/svábokról az iskolában oktatott történelmi képet, amelyben a sváb/német a fasisztával volt azonos (Végel 2012, 31-40.). A vendégmunkához lásd még Goeke (2007).

5 Az asszony két kamasz fivérét a második világháború végén megölte a partizánok közé keveredett falubeli szerb férfi. ő maga és nővére e tragédia után születtek. A szülők minden egyes nap felidézték a feldolgozhatatlan családi tragédiát, amelynek súlyát egész életében hordozza, bele is betegedett.

6 Az Új Symposion történetéhez lásd Szerbhorváth (2005a).

7 Idézzünk fel egyet a sok történet közül, amely egyedi, de az események fordulatai mégis tipikusak. 1991-ben, egy napsütéses októberi délutánon a munkából hazatérő férj a feleségével kávézik a teraszon. A családi ház nemrég épült, a férfi mérnökember, jó munkahellyel, a feleség pedagógus a helyi iskolában. Két kislányuk van, az egyik még csak óvodás, az utóbbi időben a homokozóban játszva gyakran felsír, megijed az alacsonyan szálló, Vukovár felé tartó repülőgépektől. A kávézást csengő szakítja meg, a feleség megy a kapuhoz, nincs itthon a férje, mondja a helyi kisbírónak, aki a „meghívót”, vagyis a katonai behívót hozza, s aki, kis faluról lévén szó, ahol mindenki mindenkit ismer, tudja, hogy az asszony nem mond igazat, de elmegy. Gyorsan döntenek, a férj összepakol, másnap elindul. Mivel az a szóbeszéd járja, hogy a falu kijáratait ellenőrzik, s a férfiakat nem engedik tovább, a hátsó ülésen, pokróccal letakarva utazik, az autót felesége kolléganője vezeti ki a faluból egy kukoricásba, onnan már ő indul a határra. Szegedre érkezvén megáll egy telefonfülkénél és felhívja az otthoniakat, sikerült. Egy rokon másnap áthozza a határon a feleséget és a két kislányt, s egy albérletben elkezdődik a szegedi élet.

8 Beszélgetőtársaink elképzelhetetlennek tartották, hogy korábbi barátaikat ellenségnek tartsák, kollégáik, barátaik ellen fegyvert fogjanak. Általánosabban fogalmaz Szerbhorváth György a vajdasági magyar háborús irodalomról szóló dolgozatában. „A vajdasági magyarok (...) kisebbségiek lévén, nem érez(het)ték maguknak e háborúkat - más nemzetek küzdöttek egymással nemzetállamuk létrehozásáért, a függetlenségért vagy éppen az »élettérért«. A vajdasági magyarok »téves csatatérre « kerültek” - hivatkozik a szerző Domonkos István 1971ben megjelent Kormányeltörésben címú híres versére (Szerbhorváth 2005b, 94.).

9 Egy alföldi kisvárosban él egy vajdasági házaspár, a férfi a nyolcvanas évek elején Magyarországon végezte felsőfokú agrártanulmányait, hazaköltözött, óvónő végzettségü feleségével otthon, munkahely mellett virágkertészetet indítottak el. 1994 októberében kapta a behívóját, átjött a határon, mielőtt lezárták volna, felesége az első gyermekükkel néhány hónap után követte. Nem igazán boldogultak itt, s „a rokonság is otthon volt”, ezért 1996-ban, már két gyermekkel visszaköltöztek szülőfalujukba s újra gazdálkodni kezdtek, azt hitték, végre rendeződnek a viszonyok. Két év után azonban úgy érezték, egyre rosszabb, s még a bombázások előtt visszajöttek. Kétszer kezdték el felépíteni magyarországi életüket és kertészetüket.

10 Egy 1972-ben született fiatalasszonyt említünk példaként, aki egy zárt, magyar, földművelő falusi közösségben nőtt fel, ám nem helyben képzelte el a jövőjét. Az első lépés a városi középis- 
kola volt, ahol kinyílt számára a világ, és ekkor érlelődött meg benne a döntés, hogy Magyarországon akar élni; nagyon rossz élményei voltak a szerb diákokkal. Főiskolai tanulmányát a Vajdaságban kezdte meg, de félbeszakította, mert akkor már Szegeden dolgozó ismerősei segítségével sikerült elhelyezkednie. Tanulmányait már Magyarországon fejezte be, s itt ismerte meg a behívó elől menekült vajdasági férjét is. ő a hagyományos falusi életformából és a hátrányos kisebbségi sorsból egyszerre lépett ki az áttelepedéssel. A fiatalasszony gyerekei megszületése óta is folyamatosan képzi magát, építi szakmai pályáját és nyitott minden új lehetőségre. Szívesen költözne akár Budapestre is, férje azonban nem támogatja ezt, ő ugyanis nehezebben alkalmazkodott a magyarországi élethez, és legjobban ma is vajdaságiak között érzi magát.

11 2011. október 2-án az A38-as hajón Vajdaságban élő/élt vagy onnan áttelepült képzőművészek alkotásaiból nyílt kiállítás „20 éves az újvidéki emigráció” címmel. 2011 pünkösdjén pedig részt vehettünk egy szegedi rendezvényen, a Tisza-parton az ország különböző részein élő vajdaságiak találkoztak. Az ötletgazda és szervezö többször is „palesztinok” találkozójáról beszélt. Az „emigráció” fogalmának vagy a „palesztin” metaforájának használata nem véletlen, egyrészt arra utal, hogy a migrációt a háború kényszerítette ki, másrészt az „otthontalanság” érzésére, amely néhány migráns történetében húsz évvel az áttelepedés után is meghatározónak tünik.

12 „Az integráció egy hosszabb folyamat. A személyek elveszítették addigi világukat, kapcsolataikat, ezt a gyászhoz hasonló folyamat kíséri, de itt nincs sírhely, csak otthagyott emlékek és kapcsolatok. Az integráció után is megmarad a személyekben egy mély, de már kevésbé kisebbségi érzésvilág, amivel kötődik az eredeti lakóhelyéhez, múltjához, egykori identitásához." (Szabó 2011). A „gyász" fogalmát használta egy pszichológus interjúpartnerünk is, amikor a kényszerü migrációról, a háborúról, mint a korábbi értékek, mindenekelőtt a különböző nemzetiségek békés együttélésének lehetőségét drámaian megkérdőjelező tapasztalatról beszélt.

13 Tapasztalataink szerint ahol a döntést a távozásról a férj egyedül hozta meg s a feleség kényszerüen követte őt, ott Magyarországon előbb-utóbb válás következett. Mivel a párkapcsolatok történetét nem ismerjük, csak feltételezzük, hogy már az elvándorlás előtt aszimmetrikus lehetett e párok kapcsolata, s a migráció felerősítette a feszültségeket.

14 Az áttelepedés különösen nehéz volt azoknak, akik magyar házastársukat követték Magyarországra, de ők maguk nem magyarok. Mint az a zeneművész, egyetemi zenetanár szerb asszony, aki ugyancsak muzsikus férjével és öt gyermekükkel telepedett le egy fővárosközeli településen. Nem csak a karrierjét, gazdag társadalmi életét kellett feladnia, de légüres térbe is került, nem ismerte a nyelvet, nem tudott kapcsolatokat építeni. Évekbe került, míg a családján kívüli világban is megtalálta a helyét.

15 Szegeden igyekeztek támogatni, segíteni a nagy számban a városba érkező vajdaságiakat. Húsz év távlatából már ironikus hangon, nevetve emlékezett egy férfi arra, hogy mi történt azután, hogy 1991 őszén a családdal áttelepedett: „Jártunk autóval a Vöröskereszt, meg mindenféle segélyekért. Nagyjából ez történt. Azóta is van még egy húsz-harminc fogkefém. Annyit adtak, fogkefét. Minden csomagban volt egy fogkefe. Volt nagyon sokáig ilyen konzervdobozban levespor. Arra rá sem tudok nézni!"

16 Egy 1992-ben Szegedre érkezett férfi erre így emlékezett: „Próbáltuk egymást megtalálni, és akkor sikerült is hál'istennek. És tulajdonképpen azt kell, hogy mondjam, hogy fontos, nagyon fontos volt az a kapcsolat az én számomra, mert információkat, azt nagyon sokat kaptunk egymástól. Ugye nagyon sokan voltunk különféle helyzetekben, és akkor... És mindenki tudott a másiknak valami újat mondani, meg segiteni. Azt is el kell, hogy mondjam, hogy pénzben is segitettük egymást. Egymás vállalkozásait, adtunk egymásnak kölcsönt, mit tudom én. (...) Egy ilyen, nem mondom, hogy önsegélyező szervezet, vagy kapcsolat, de müködött, és ez azért jó volt. De ne tessék csak úgy érteni, hogy nem tudom én milyen vállalkozáshoz, hanem... Hát bármi ilyen vonatkozású dologban ugye. Ha megszorultunk, akkor tudtunk egymáson segíteni."

17 Dahinden Svácjban élő, az országba különböző időszakokban telepedett koszovói albánok kapcsolathálózatainak alapos feltárása alapján jutott arra a következtetésre, hogy korántsem jellemző mindenkire az otthoniakkal, a kibocsátó otthonnal való intenzív kapcsolattartás, s a transznacionális migráció és kapcsolatok fogalmának körültekintő alkalmazására szólít fel (Dahinden 2005).

18 „Mit den Begriffen transnational und Transnationalisierung werden hier grenzüberschreitende Phänomene verstanden, die - lokal verankert in verschiedenen Nationalgesellschaften - 
relativ dauerhafte und dichte soziale Beziehungen, soziale Netzwerke oder Sozialräume konstituieren" (Pries 2010, 13.).

19 Pries a nemzetállamok határain túllépő geográfiai és társadalmi terek, társadalmi kapcsolatok ideáltípusait annak érdekében alkotja meg, hogy túllépjen a módszertani nacionalizmus elméleti és szemléleti keretein, és tisztázza a transznacionalizmus mint társadalmi tér és egyúttal mint kutatási program létjogosultságát és sajátosságait. Az ideáltípusok a következők: 1. internacionalizálódás, 2. szupranacionalizálódás, 3. globalizálódás, 4. renacionalizálódás, 5. glokalizálódás, 6. diaszpóra-internacionalizálódás, 7. transznacionalizálódás. A különböző folyamatok különböző szinteken egyidejűleg hathatnak, egymást erősíthetik, gyengíthetik vagy éppen egymásnak is szegülhetnek. Az internacionalizálódás példái az olyan szervezetek, mint az ENSZ, az OECD vagy a Világbank, míg a szupranacionalizálódás kézenfekvő példáit az Európai Unió politikai intézményei jelentik. A renacionalizálódás kapcsán a Szovjetunióra és Jugoszláviára gondolhatunk mint korábban multietnikus, többnemzetiségü föderális országokra, amelyek több kisebb nemzetállamra bomlottak szét. A globalizáció átszövi világunkat, a glokalizáció a globális intézmények, technikák (mint a McDonald's vagy a globális internettechnológia) egyenlőtlen hatalmi struktúrákat létrehozó vagy azokat erősítő lokális beágyazódását jelenti. A diaszpórák internacionalizálódását a szétszóratásban élő zsidók példázzák, de Pries említi a Vatikán különböző misszióit vagy a száműzött chilei migránsokat. Pries értelmezésében a diaszpórák esetében meghatározóak az erős és identitásképző központok, a tőlük függő periférikus földrajzi és társadalmi tereket összekötő kapcsolatok (Pries 2010, 20-24.).

20 A transznacionális tér priesi definíciója: „configurations of social practices, artefacts and symbol systems that span different geographical spaces in at least two different spaces in at least two nation-states (...)" (Pries 2001, 18.)

21 Levitt és Glick Schiller a transznacionális tér priesi definíciójához igen hasonló módon, de Bourdieu mezőelméletéhez visszanyúlva transznacionális társadalmi mezőről írnak „mint társadalmi kapcsolatok többszörös, egymással összefüggő hálózatairól, amelyeken keresztül eszmék, gyakorlatok és források egyenlőtlen cseréje, szervezése és transzformációja zajlik" (Levitt, Glick Schiller 2004, 9.). A szerzők különbséget tesznek az egyes emberek tényleges társadalmi kapcsolatai és gyakorlatai (ways of living), valamint érzelmi kötődései (ways of belonging) között. Utóbbi nem feltételezi azt, hogy a migráns tényleges kapcsolatokat tartson fenn az otthoniakkal, rendszeresen hazalátogasson stb., hiszen egy-egy jel, szimbólum vagy esemény, cselekvés kifejezheti érzelmi kötődését és identitását (Levitt, Glick Schiller 2004, 11.). E megközelítés szerint a délvidékiek báljai Szegeden transznacionális térben/mezőben zajló eseménynek tekinthetők, ahol a Vajdaságból érkezett zenészek repertoárja, a zene által felidézett emlékek, a honvágy, az itt kiállított és megvásárolható vajdasági magyar könyvek, kalendáriumok kifejezik a résztvevők kötődését szülőföldjükhöz, megerősítik a migráns közösség összetartozását és vajdasági magyar identitását.

22 Szabó 39 olyan kishegyesi és feketicsi vendégmunkással készített interjúkat, akik a kilencvenes években legalább egyszer és legalább három hónapot dolgoztak Magyarországon. A legtöbben 1993-ban vállaltak munkát először Magyarországon, abban az évben, amikor radikálisan megváltoztak az emberek megélhetési lehetőségei; elszabadult az infláció, összeomlott a gazdaság, az általános fizetőeszközzé a német márka vált. Fontos megállapítása, hogy míg a hetvenes években a németországi vendégmunka lehetőségével a szegényebb egzisztenciák éltek, addig a kilencvenes években a jómódú, gazdagabb rétegekhez tartozó, munkahely mellett jellemzően gazdálkodó családokból kerekedtek fel a férfiak. Ezt azzal magyarázza, hogy a hetvenes években Németország számára nélkülözhetetlen volt a külföldi munkaerő, ezzel szemben a kilencvenes évek átalakuló, munkanélküliség sújtotta magyar gazdaságában csak azok jutottak lehetőséghez, akik magyarországi kapcsolatokkal, ismerősökkel rendelkeztek, s akik egyfelől a magyarországi tartózkodás költségeit, másfelől a határátlépéssel járó kiadásokat is fedezni tudták (Szabó 2003, 244-245.).

23 Ha e bevezetőben csak egy jegyzetben is, fontosnak tartjuk említeni Thomas Faistot, aki Priestől némileg eltérően a transznacionális társadalmi teret „kötelékek, hálózatokban és szervezetekben elfoglalt pozíciók, valamint szervezeti hálózatok olyan kombinációinak tekinti, amelyek átnyúlnak az államok határain”. A transznacionális társadalmi tér típusait a 
transznacionális kapcsolatokban mobilizált tőkefajták szerint azonosítja. A „transznacionális rokonsági csoportok" (transnational kinship groups) olyan transznacionális teret hoznak létre, amelyben a reciprocitás az alapvető forrás, e típus példájaként a fizetésüket az otthonlévő családtagoknak átutaló vendégmunkásokat említi. A „transznacionális körforgások” (transnational circuits) olyan teret jelenítenek meg, amelyben a legfőbb forrást a szereplők kölcsönös kötelezettségeinek és elvárásainak megfelelő csere jelenti, e térben javak, emberek, információk szakadatlan áramlása zajlik a kibocsátó és a befogadó országok között. Példaként Faist a kínai, libanoni és indiai üzletemberek kereskedelmi hálózatait említi. A transznacionális közösségek tereiben a szolidaritás a legfőbb forrás; közös eszmék, hitek, szimbólumok, a kollektív identitás kifejeződései. A transznacionális közösségeket példázzák a zsidó, örmény, palesztin vagy kurd diaszpórák, illetve az USA és Mexikó közötti vagy a mediterrán frontierrégiókban élő, kollektív identitással jellemezhető csoportok (Faist 2000, 195-198.).

24 S ahogy ő értelmezi a helyzetét: „Én nem véletlenül jöttem vissza. Én úgy látom, hogy nekem Magyarkanizsa az otthonom. Ez az a falu, ahol tudok élni. Jól van, most elvagyunk mi Szegeden is, de nem nagyon tudnám elképzelni, hogy máshol éljek. Úgy is gondoltam, amikor elmentem, hogy nyugdijasként visszajövök. Csak hát úgy alakult, hogy én hamarabb visszajöttem. (...) Tulajdonképpen itt a miloševići politikai rezsimen kívül én mindent sajnáltam itt hagyni. A várost, az embereket is, a Tiszát is... Én nem úgy mentem el, hogy el akartam menni..."

Az asszony szavaival: „(...) ott kell, hogy éljek, mert odaköt a munkahelyem. Erról az jut az eszembe, hogy akárhányszor hazajövök, tehát havonta egyszer, addigra mindig meghal legalább két-három ember az ismeretségi körömból vagy a rokonságomból. És ezt egyszerre nagyon rossz hallani. Tehát az alakult ki, hogy se itt, se ott nem érzem magam otthon. Ha ott vagyok, akkor ez hiányzik, ha itt vagyok, akkor az hiányzik."

26 A már bemutatott egyetemi oktató szerint az a vajdasági, aki már hosszú évek óta Magyarországon él, nem biztos, hogy boldogulna a megváltozott szerbiai viszonyok között. A „mindennapi élet kis finom cselei" közé tartozik az a mód, ahogy a hivatalokban, a hivatalnokokkal viselkedni kell, s ami nemcsak a megfelelő nyelv használatát, hanem a gesztusokat is jelenti. „....aki Magyarországról jön ide, az pórul jár. Hiába hivatkoznak az emberi jogokra, ez nem sokat... Magyarországon arra kell hivatkozni, nekem mindig azt mondták, hogy az emberi jogokra kell hivatkozni. Ezt egy szerb mondta egyébként. Azt mondja, mindig egy csokor virág meg az emberi jogok." Ezzel szemben Szerbiában, véleménye szerint, a hangerő hatásosabb, de a doktori cím is meglágyíthatja a hivatalnok szívét.

27 A kedvezményes honosítás ellenére a szülőföldön való megmaradás politikája érvényben maradt.

28 A következő interjúrészletben megfigyelhető érvelés gyakran visszatért a beszélgetések során. „Na, most én meg úgy voltam vele, hogy hát bárhova megyek, bármelyik országba... Szóval mindenhol, hogy is mondjam, ilyen vendégmunkásként fognak rám nézni. Mert hát ugye az volt, hogy az embernek megvan a saját szakmája, én nem is gondoltam soha arra, hogy én menekültként jelentkezzek be bárhol, meg mit tudom én micsoda, tehát én azt gondoltam, hogy a leghelyesebb vagy a leglogikusabb az, hogy én az anyaországba megyek, és hát ott próbálok majd szerencsét."

29 Említettük már a vajdaságiak által alapított és jellemzően vajdaságiakat foglalkoztató budapesti nyomdát. A szegedi piac ügyvezető igazgatója néhány évig egy vajdasági magyar volt, aki sok embert vett föl, de „aki bevált, az mind vajdasági volt”.

30 A vajdasági magyar írók, zenészek, művészek, irodalomárok stb. jellemzően tudtak támaszkodni magyarországi kapcsolataikra, amelyek már jóval az áttelepedésük előtt kialakultak és intenzívek voltak.

31 A bizalom, a meghittség jele a nyelvváltás is: „(...) amikor az irodába úgy hirtelen betoppan ez, betoppan az, négyen-öten hirtelen a Vajdaság több területéról megjelennek. És szabadkai, topolyai vagy újvidéki, hirtelen ott, és én nézek, és akkor, na, "összefújta a szemetet már megint itt a szél«, és akkor itt vagyunk egy rakáson. És akkor így jókat nevetünk. Az érdekes, ilyenkor mindig leülnek a fiúk, és akkor mindig - mindenki Magyarországon él már, több éve fejezték be az egyetemeket, föiskolákat is - és szerbül ugyanúgy elkezdik. És szerbül kezdik így egymás közt fricskázni is egymást, meg így beszélgetni is, hogy azért úgy a társaságukban ez azért megmaradt. Ez, amikor így leülnek együtt, és akkor kicsikét a szerbet úgy nyomják bele a társalgásba." A szerb titkos nyelvként is működik, amikor a tárgyalás vagy beszélgetés során átváltanak, hogy mások ne értsék őket. 
32 Mindössze egy migránssal találkoztunk, aki azt mondta, megbánta, hogy 1998-ban Magyarországra jött át tanulni, s aztán itt maradt. Ezt az erősödő magyarországi nacionalizmussal magyarázta.

33 Van, aki ilyen helyzetekre „rejtőzködéssel” válaszolt, igyekezett az akcentusát levetkőzni, nem beszélt arról, hogy honnan jött. Egy egyetemi diák a szerb jelzőhöz tapadó képzeteket (balkáni, primitív, vad stb.) felnagyítva fordult az őt rendre „leszerbező” kollégiumi társa felé, mondván: ,jó, akkor szerb vagyok, de tudod milyenek a szerbek, éjszaka elvágom a torkodat holnap reggelre”.

34 Egy Magyarországon doktori tanulmányait folytató zentai történész a kérdésre, hogy mit sajnálna itt hagyni, ha végleg el kéne költöznie, így válaszolt: „Zentát. Egyértelmü, de vannak más dolgok is (...) Újvidékkel is vannak szép emlékeim is, Szabadkával is egy-kettő́t, de Zenta hiányozna elsősorban. Tehát, ha emigrálnánk, akkor Zentát is magammal vinném valamilyen formában, de én úgy hiszem, ez elsősorban a zentaiaknak egy... egy nagy teher a vállukon, hogy soha nem tudják kitépni a gyökereiket. Egy-egy településnek vannak ilyen jellegzetességei, ilyen kötödések, amelyek nagyon nem engedik az embert, ezért nem ürült ki, hála Istennek, Zenta eddig, és reméljük, hogy így is marad."

\section{Irodalom}

Bondár A. (2005): Női migráció és változó nemi szerepek. Széki asszonyok Budapesten. In: Feischmidt M. (szerk.): Erdély-(de)konstrukciók. Néprajzi Múzeum, PTE Kommunikáció- és Médiatudományi Tanszék, Budapest, Pécs, 163-183. (Tabula könyvek; 7.)

Brubaker, R. (1998): Migration of ethnic unmixing in the "New Europe". International Migration Review, 4., 1047-1065.

Basch, L., Glick Schiller, N., Szanton Blanc, C. (1994): Nations unbound. Transnational projects, postcolonial predicaments and deterritorialized nation-states. Routledge, London, New York

Bodó J. (szerk.) (2008): Migrációs folyamatok - közösségi megjelenítések. Státus Kiadó, Csíkszereda

Dahinden, J. (2005): Contesting transnationalism? Lessons from the study of Albanian migration networks from former Yugoslavia. Global Networks, 2., 191-208.

Erőss Á., Filep B., Rácz K., Tátrai P., Váradi M. M., Wastl-Walter, D. (2011a): Tanulmányi célú migráció, migráns élethelyzetek: vajdasági diákok Magyarországon. Tér és Társadalom, 4., 3-19.

Erőss Á., Filep B., Rácz K., Tátrai P., Váradi M. M., Wastl-Walter, D. (2011b): Stratégie éducative ou stratégie migratoire? Les étudiants de Voïvodine en Hongrie. Géo-Regards Revue Neuchâteloise De Géographie, 4., 169-186.

Erőss Á., Váradi M. M. (2013): „Temerin - az én hazám”: változó interetnikus viszonyok magyar szemszögből és rajzban elmesélve. Tér és Társadalom 2., 171-188.

Faist, T. (2000): Transnationalization in international migration: implications for the study of citizenship and culture. Ethnic and Racial Studies, 2., 189-222.

Feischmidt M. (2004): A határ és a román stigma. In: Kovács N., Osvát A., Szarka L. (szerk.): Tér és Terep. Tanulmányok az etnicitás és identitás kérdésköréból III. Akadémiai Kiadó, Budapest,43-58.

Feischmidt M. (2005): A magyar nacionalizmus autenticitás-diskurzusainak szimbolikus térfoglalása Erdélyben. In: Feischmidt M. (szerk.): Erdély-(de)konstrukciók. Néprajzi Múzeum, PTE Kommunikáció- és Médiatudományi Tanszék, Budapest, Pécs, 7-32. (Tabula könyvek; 7.)

Feischmidt M., Zakariás I. (2010): Migráció és etnicitás. A mobilitás formái és politikái nemzeti és transznacionális térben. In: Feischmidt M. (szerk.): Etnicitás. Különbségteremtö társadalom. Gondolat, MTA Kisebbségkutató Intézet, Budapest, 152-169.

Fox, J. E. (2005): Vándorló nemzet(i) - identitások. Erdélyi vendégmunkások Magyarországon. In: Feischmidt M. (szerk.): Erdély-(de)konstrukciók. Néprajzi Múzeum, PTE Kommunikáció- és Médiatudományi Tanszék, Budapest, Pécs, 103-122. (Tabula könyvek; 7.)

Gábrity E. (2013): A vajdasági magyar ingázók nyelvi identitása és ideológiái. Tér és Társadalom 2., 118-130.

Gábrity Molnár I., Mirnics Zs. (szerk.) (2001): Fészekhagyó vajdaságiak. Magyarságkutató Tudományos Társaság, Szabadka 
Goeke, P. (2007): Transnationale Migrationen. Post-jugoslawische Biografien in der Weltgesellschaft. transcript Verlag, Bielefeld

Gödri, I. (2004): Etnikai vagy gazdasági migráció? Az erdélyi magyarok kivándorlását meghatározó tényezők az ezredfordulón. Erdélyi Társadalom, 1., 37-54.

Gödri I. (2005): A bevándorlók migrációs céljai, motivációi és ezek makro- és mikrostrukturális háttere. In: Gödri I., Tóth P. P. (szerk.): Bevándorlás és beilleszkedés. KSH Népességtudományi Kutatóintézet, Budapest, 69-131. (KSH NKI Kutatási Jelentések; 80.)

Gödri I. (2010): Bevándorlás és etnicitás - összefüggések nyomában. In: Hárs Á., Tóth J. (szerk.): Változó migráció - változó környezet. MTA Etnikai-nemzeti Kisebbségkutató Intézet, Budapest, 87-124.

Gustafson, P. (2004): More or less transnational: two unwritten papers. In: Povrzanović Frykman, M. (ed.): Transnational spaces: disciplinary perspectives. Willy Brandt Conference Proceedings. Malmö University, 64-76.

Jordan, B., Düvell, F. (2003): Migration. The boundaries of equality and justice. Polity Press, Cambridge

Levitt, P., Glick Schiller, N. (2004): Conceptualizing simultaneity: a transnational social field perspective on society. International Migration Review, 3., 595-629.

Melegh A., Molodikova, I. (2009): Bevándorlói interjúk elemzése. In: Melegh A. (szerk.): A bevándorlási és integrációs statisztikai rendszer fejlesztése. KSH, Budapest

Nagy I., Tátrai P. (2013): A migráció hatása Temerin népességnövekedésére és etnikai szerkezetének átalakulására. Tér és Társadalom 2., 134-146.

Pannonymus, S. (2007): Egy imigráns vallomásai. Igazi népmese. Regio, 4., 56-79.

Portes, A. (2003): Conclusion: theoretical convergencies and empirical evidence in the study of immigrant transnationalism. International Migration Review, 3., 874-892.

Pries, L. (2001): The approach of transnational social spaces. In: Pries, L. (ed.): New transnational social spaces. International migration and transnational companies in the early twenty-first century. Routledge, London, New York, 3-33.

Pries, L. (2010): Transnationalisierung. Theorie und Empirie grenzüberschreitender Vergesellschaftung. VS Verlag für Sozialwissenschaften, Springer Fachmedien Wiesbaden $\mathrm{GmbH}$

Pulay G. (2005): A vendégmunka mint életforma. Széki építőmunkások Budapesten. In: Feischmidt M. (szerk.): Erdély-(de)konstrukciók. Néprajzi Múzeum, PTE Kommunikáció- és Médiatudományi Tanszék, Budapest, Pécs, 143-162. (Tabula könyvek; 7.)

Rácz K. (2012): Stories of welfare. The economic aspects of migration. Előadás. TRANSMIG záró konferencia, Szeged, Szabadka, 2012. december 3-4.

Ristić, D., Nagy I., Kicošev S. (2013a): Szerb menekültek Temerinben: identitás és integráció. Tér és Társadalom, 2., 147-158.

Ristić, D., Nagy I., Kicošev S. (2013b): „Hely”és identitás: egy temerini középiskolások körében végzett vizsgálat néhány tanulsága. Tér és Társadalom, 2., 159-170.

Szabó Á. (2003): Vajdaság - Kishegyes és Feketics. Vendégmunka és migrációs potenciál a két településen. In: Örkény A. (szerk.): Menni vagy maradni? Kedvezménytörvény és migrációs várakozások. MTA Kisebbségkutató Intézet, Budapest, 241-255.

Szabó E. (2011): Többség? Kisebbség? Záródolgozat. Semmelweis Egyetem, Károli Gáspár Református Egyetem Sapientia Szerzetesi Hittudományi Főiskola, Budapest

Szerbhorváth Gy. (2005a): Vajdasági lakoma - az Új Symposion történetéról. Kalligram Könyvkiadó, Pozsony

Szerbhorváth Gy. (2005b): Háború, irodalom - háborús irodalom a vajdasági magyar irodalomban (1991-2005). Regio, 3., 89-119.

Szónokyné Ancsin G. (1997): Külföldi bevándorlók és befektetők Szegeden. Tér és Társadalom, 3., 143-156.

Takács Z., Tátrai P., Erőss Á. (2013): A Vajdaságból Magyarországra irányuló tanulmányi célú migráció. Tér és Társadalom 2., 77-95.

Tátrai P., Kocsis K., Gábrity Molnár I., Takács Z. (2013): A Vajdaságot érintő migráció és annak történeti előzményei. Tér és Társadalom 2., 35-54.

Tóth P. P. (1997): Haza csak egy van? Menekülók, bevándorlók, új állampolgárok Magyarországon (1988-1994). Püski Kiadó, Budapest 
Váradi M. (2013): Migrációs történetek, döntések és narratív identitás. A tanulmányi célú migrációról - másként. Tér és Társadalom, 2., 96-117.

Váradi M., Erőss Á. (2013): „Kulturálisan vagyunk magyarok, mentalitásban szerbek vagyunk szerintem, igen.” Magyarországon élő vajdasági magyar migránsok és a jugóbuli. Tér és Társadalom, 2., 55-76.

Végel L. (1996): Modernitás és kisebbség. Korunk, 11., 25-44.

Végel L. (2012): Bünhődés. Úti szövegek. Noran Libro, Budapest

Wimmer, A., Glick Schiller, N. (2002a): Methodological nationalism and the study of migration. Archives of European Sociology, 2., 217-240.

Wimmer, A., Glick Schiller, N. (2002b): Methodological nationalism and beyond: nation-state building, migration and the social science. Global Networks, 4., 301-334.

Zakariás I. (2008): Identifikációs narratívák Magyarországra áttelepült erdélyi diplomások élettörténeteiben. Regio, 3., 135-167.

Zombory M. (2011): Az emlékezés térképei. Magyarország és a nemzeti azonosság 1989 után. L'Harmattan, Budapest 